\title{
POPULAR SCIENCE
}

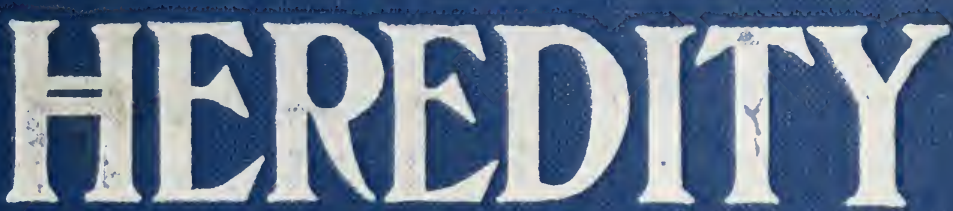

VML

QH431

5278 1900 


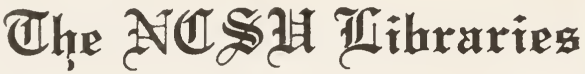

Narth Caralina Sstate Hniwersity

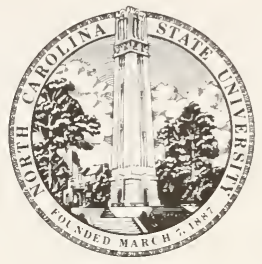

This bouk faas presented by

Javad Vakilzadeh 
This book is due on the date indicated below and is subject to an overdue fine as posted at the circulation desk.

EXCEPTION: Date due will be earlier if this item is RECALLED.

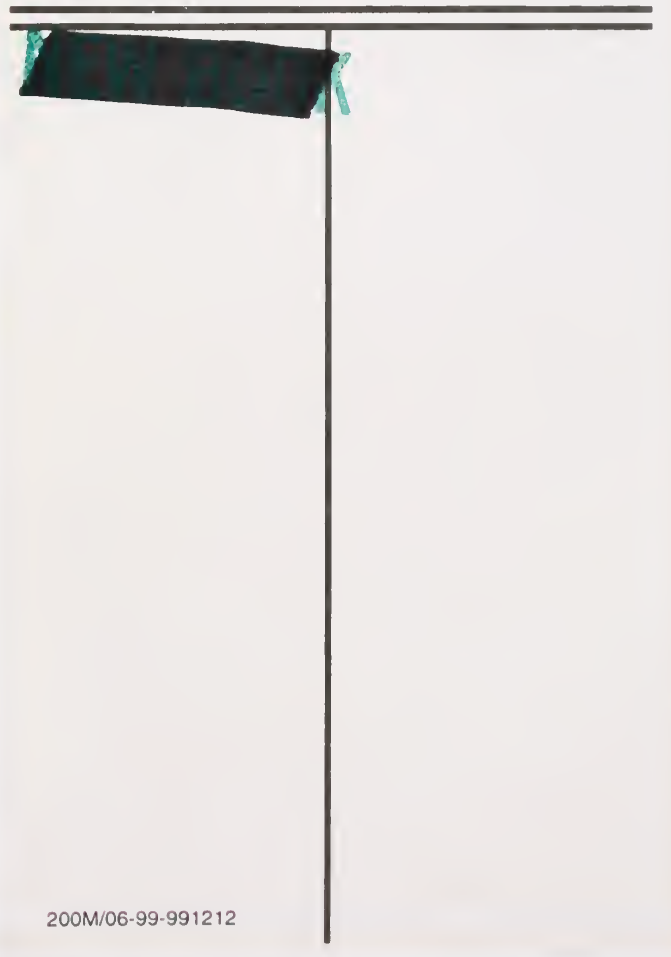





\section{H E R E D I T Y}

BY

C. W. SALEEBY, M.D.

ACTHOR OF

"THE CYCLE OF LIFE," "EVOLCTION THE MASTER-KFI," ETC.

NEW YORK

FREDERICK A. S'TOKES COMPANT

PUBLISHERS 
Printed by ballaxtrye, Haxsos a co. At the Ballantyne press 


\section{CON'TEN'TS}

CHAP.

PAGF:

I. INTRODUCTORY • $\quad$ • $\quad$ •

II. The Modes of Reproduction . . . . 17

III. The Facts and Function of Sex . . . 24

IV. The Biometric Study of Heredity . • . 39

V. The Facts and Laws of Variation . . . 47

VI. The Origin of Variations . . . . . . 49

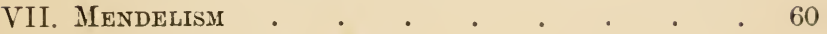

VIII. REVERSION . . . . . . . . 64

IX. The Theories of Heredity . . . . . 68

X. The Inheritance of AcQdirements . . . 71

XI. The Relative Importaxce of Heredity and Environgent . . . . . . . 84

XiI. Heredity and "Physical Degeneration" • . 92

XIII. Heredity and Disease . . . . . . 103

XIV. Mental Heredity . . . . . . . 115

Subject Index . . . . . . . 117

INDEx to NaMeS . . . . . . . 118 



\section{H E R E D I T' Y}

\section{CHAPTER I}

\section{N T ROD UCTOR Y}

Heredity is a general term which expresses the fact that the individuals of all animal and vegetable species tend to beget their like; "as is very natural," we feel inclined to add. This comment expresses, in popular language, the conviction that heredity is a "law of Nature," that it results from the action of constant causes which may be capable of analysis. We expect to find the child like his father, partly because we have frequent experience of this likeness; but we also feel that, had we had no experience of it, we would have predicted its occurrence. It "stands to reason" that a child must resemble his father in greater or less degree; and it will be our business in the following pages to inquire into the manner of a sequence so reasonable.

But, on the other hand, the child, when he grows up, is not found to be his father's "double." In some measure, however slight, he differs. This difference might be attributed, in all cases of sexual reproduction, to the fact that the child is his mother's child as well as his father's. But even 
where the new individual has but one parent, as in cases of what is called parthenogenesis, it is not an exact replica of that parent; and the same is true even where sex is unknown and reproduction is observed in its simplest form. This difference between the begetting and the begotten might conceivably be due to the fact that the surrounding circumstances or environment of the one were not precisely identical with those of the other. But even when the environment is the same for both, this difference is still found, and we express it by the general term, Variation.

This fact, also, is one of constant experience; but our opinion of it is not that it "stands to reason," but rather that it is irrational. We incline to think that heredity is the "law," variation the "accident," or the exception to the law. Strictly speaking, we fancy, there "ought to be" no such thing as variation; but of course it is unreasonable to expect that heredity shall always be perfect, and "something or other" is doubtless often apt to mar its accuracy, thus leading to that anomalous (or, in English, lawless) occurrence which we call variation.

On second thoughts, however, we see that our notions are quite unphilosophic. Causation is nonversal ; and variations cannot be regarded as "flukes" or flaws in heredity, but must be subject to laws of their own. It will be part of our business, then, in this book to ask ourselves whether variation, as well as heredity, does not "stand to reason," in the sense that it is capable of a rational explanation.

In our study of these matters, we might save ourselves much trouble by the adoption of a metaphorical 
mode of speech. The fact that it saves us trouble should put us on our guard, there being no royal road to knowledge, least of all by the way of metaphor. Nevertheless we constantly find ourselves talking, in fine language, of heredity and variation as two "forces"- that blessed word! These "forces" are "inherent in living matter"-a phrase which really means that we intend to save ourselves the trouble of asking how they come to be "inherent" -and there is eternal opposition between them. The one "force" is ever seeking-since we have got so far as to call heredity a "force," we may as well personify it-to preserve the type, whilst the aim of the other is to alter it. Sometimes the one all but vanquishes the other; sometimes they agree to a compromise. .. . This may be poetry, or journalese, or several other things, but it is certainly not science, or, at any rate, not adequately scientific. Whilst passing this stricture upon a common manner of expressing the facts in question, we may yet admit that it has a certain symbolic value, and may be employed on occasion, as long as we clearly understand that our language is not literal but metaphorical. For instance, we shall see that this symbolising of heredity and variation as opposing but complementary forces is of value in the comparison between the man and society-the individual organism and the social organism. Plainly the conservative forces of society are the analogue of heredity, and the liberal forces are the analogue of variation; concerning which we must say much more anon.

There is yet another mode of conceiving the facts. This may be described as an attempt to 
base a defence of a non-scientific doctrine upon a present defect in scientific knowledge. Our knowledge of the causes of variation is-or, rather, very recently was-extremely uncertain and scanty. Upon this evanescent circumstance is erected some such theory as the following: Heredity is undoubtedly a "law of Nature," and may some day be completely explained by science. But variation, on the other hand, is found inexplicable by science - cannot be reduced to law. Now without varia. tion there can be no organic evolution, as men of science themselves assert. But organic evolution, ever making for progress, is clear evidence of Purpose behind things. Hence we may accept the theory of organic evolution, which it is no longer possible to doubt; but must believe that Creative Design is not incompatible with it. The Deity, however, acts not, as we used to think, by instantaneous creation, but by gradual creation through evolution. The evolutionary process is directed towards the ultimate purpose by the gradual introduction of such variations as (being perpetuated by heredity) make ever for progress. This is the reason why men of science cannot explain variation; and since the whole process of organic evolution depends upon variation, they will, sooner or later, be compelled to recognise the Divine Hand as the prime mover which is above all law. Thus are orthodoxy and evolution reconciled; and the doctrine of teleology, or purpose, or final causes is found to be indispensable to the adequate statement of the scientific theory.... No direct and present criticism of this position is necessary; 
but we shall devote much space to a discussion of the causes of variation, recognising that this question is absolutely fundamental to the theory of organic evolution.

And here it is proper to insist upon the importance of our subject. Heredity is, of course, a very interesting matter, and so is the occurrence of variation side by side with heredity. But we study these things to-day in a very different attitude from that of, say, a hundred years ago; for we know their significance, their bearing upon much greater matters. The astronomer of the fifteenth or sixteenth century might be interested in tracing the exact movements of a planet. These were facts of Nature; but, if they had any ulterior significance, it was only in illustrating the habits and customs of the great Spirits which even Kepler supposed to inhabit and drive the heavenly bodies. But nowadays, thanks to Kepler and Galileo and Newton, the astronomer knows the laws of motion and gravitation, and the movements of a planet mean something for him. Similarly the facts of heredity and variation mean something for the biologist of to-day, and he studies them hardly for themselves at all, but because of their bearing on organic evolution. Now organic evolution is not only the leading fact of biology, but is the basis on which Herbert Spencer re-erected the sciences that spring from biology, such as the science of mind, the science of society, and the science of morality. Hence the importance of heredity and variation is cardinal, their elucidation constituting a very corner-stone in that great 
structure of organised and unified knowledge of which the theory of evolution is the architectonic principle.

In discussing the problems of heredity, it is necessary very fully to consider certain changes which are found to occur in all individual organisms, animal and vegetable. These changes are the result of the individual experience-the result of the series of relations between the individual and the environment. Considered from this point of view, they might be called adaptations, since they may all be included under the products of adaptation. Other names may be employed. These changes necessarily cause each individual to vary from the type of its species, from even its immediate ancestors, its brothers and its sisters. Hence they might be called variations. But if we used this term it would be necessary to employ qualifying adjectives, so as to point the distinction between these variations and those which depend upon the innate or germinal characters of the individual. These last might be termed blastogenic variations, whilst the changes produced in the individual body by its converse with its surroundings might be called somatogenic. But I do not propose to employ these terms at all, my reason being that they do not adequately emphasise the cardinal and all-important distinction (as we now see it) between innate and acquired characters. Hence the term variation will be strictly confined hereafter to those changes from the specific type which are innate and which must now be regarded as really not distinct in origin from the characters which are obviously derived from the parent. Those 
so-called somatogenic variations, however, which depend not upon anything derived from the parent, save, perhaps, the inherited power of adaptability, will not be called variations at all, but will always be termed acquirements. The more familiar phrase is acquired characters, but I follow Mr. Archdall Reid in using the shorter and quite unequivocal word.

Accepting this terminology, then, we have to consider acquirements as characters which may often be indistinguishable, or all but indistinguishable, from true variations, since these, though innate, may not appear for years; but which are always to be distinguished in theory, not only because they have a totally different origin, but also because they have totally different consequences. Variationsi.e. new inborn characters - are unquestionably transmissible by heredity, else there could scarcely be any organic evolution; but the transmission of acquirements is a matter of keen controversy, and the measure of its occurrence, if it occurs at all, must be carefully considered in a special chapter. Obviously the question is of cardinal importance, not only to the man of science, but also to the man of action, for our practice must be gravely affected, accordingly as we believe that the results of education can or can not be transinitted to our children. If they can, one method of ennobling our race is clearly indicated; if they cannot, another and a very different method is as clearly demonstrated. ${ }^{1}$

Our subject might thus conveniently be arranged under three leading terms - heredity, variation,

1 See "The Future Evolution of Man," in the volume, "Organic Evolution." 
acquirements. In discussing each of these, we are concerned chiefly with bodily or physical characters. But we would do very ill to study only these and there to rest content. It will be necessary thereafter briefly to introduce the consideration of the facts and possibilities of mental heredity, mental variation, mental acquirements. In so doing we not only complete our study of the subject, not only consider matters of great interest in themselves, but are also preparing ourselves for the scientific study of the human mind, the cardinal feature of this study to-day being its recognition of the fact that man's mind is not a prime fact, but has a history.

One other aspect of this great study of heredity must also gain our attention. The inheritance of disease-disease of body and disease of mind-is a matter of vast practical importance. On none other is the public more constantly misinformed, so influenced by the erroneous ideas of, say, forty years ago. Furthermore, the study of inheritance of disease, and also the inheritance of immunity to disease, is of great scientific interest, for it throws light not only upon the nature of heredity itself, but also upon the manner in which the existing types and races of mankind have been affected by the incidence of disease in the past. It has been left to a distinguished medical observer, Mr. Archdall Reid, to show how disease has acted, and is still acting, through heredity, as an instrument of natural selection, in virtue of which mankind is constantly tending to become more and more immune to the attacks of the lowly vegetable organisms which are the active causes of nearly all disease. 


\section{CHAPTER II}

\section{THE MODES OF REPRODUCTION}

A NECESSARY preliminary to the study of heredity is a consideration of the elementary facts of reproduction. We cannot understand heredity unless we know the conditions in which it works. The modes of reproduction in the animal and vegetable kingdoms are various; there is a great difference between the reproduction of one of the higher animals and that of a bacillus which reproduces itself by simple fission, or splitting; but in each and every case heredity is observed. The child of a man is human, the child of a bacillus bacillary.

In the most primitive modes of reproduction there is no problem of heredity. We have no difficulty in understanding why the daughter bacilli should resemble their mother. They are their mothersubdivided. In the case of those plants, again, which propagate by separation of integral portions of their own person, there is similarly no problem. The new individual is simply a separated and extended portion of the old. Looking at such cases we understand how reproduction may be looked upon as neither more nor less than growth beyond the limits of the individual organism. The laws of this growth and the circumstances which determine the limits of the individual organism are certainly worthy of study, but they do not directly concern the student of heredity. Therefore, though we shall have occasion later to refer to the simplest modes of 
reproduction, as in the case of the bacteria, we may here leave them thus briefly noticed, and turn our attention to the mode of reproduction which may be regarded as the next in order of complexity-reproduction by gemmation. This is typically represented in the yeast plant. The new individual springs from the old by a process of budding. In the act of birth the relation of one to the other is the same as that of a large soap bubble to a small one apparently springing from it. Here also the new individual is seen to be no more than a separated part of its parent; the likeness between the two is so far from offering a problem as to be necessary and inevitable.

But we journey for only a very short distance through the animal and vegetable kingdoms before we come in each case to a mode of reproduction which persists, so far as essentials are concerned, even in the most complex and youngest speciessuch as man or the oak - with which we are acquainted.

In the case of the bacillus, reproduction involves the total evanishment of the parent. The mother is lost in her daughters. Not essentially dissimilar is the case of the yeast plant or the unicellular animals. But directly we leave these lowest forms we find ourselves confronted with a totally different state of things. The parent is no longer lost in her offspring, nor is indeed the smallest essential part of her. Further, the relation in size and in realisable complexity between the parent and that by which the parent is reproduced, becomes almost incalculable. The reproductive cell of a woman is about $\frac{1}{120}$ 
of an inch in diameter, yet her daughter may display the very tones of her mother's voice, her very gestures, even her most intimate mental peculiarities. Plainly we have now come upon a problem indeed!

It is our business, then, to examine, with the utmost particularity which the microscope and the modern methods of staining organic tissues permit, the characters of the minute but immeasurably potential cells by which the higher animals and plants reproduce themselves. We shall find, as might be expected, that they tend to be typical of cells in general-not highly differentiated. A bone cell, a nerve cell, a liver cell, a muscle cell, differ widely from the typical cell form; but the cell which is destined to give rise to all these forms, and a thousand more, is comprehensively typical of all other kinds of cells, but of none in especial.

Let us, then, consider a typical animal ovum-not of any species in particular. It is a minute globular body, usually invisible to the naked eye, and is bounded by a thin cell-membrane. The body of the cell consists of a granular, semi-solid substance, which is alive, and which is an example of protoplasm-the "physical basis of life." Somewhere about the centre of the cell there is a minute, rather denser speck, which we call the nucleus. Stained with appropriate dyes this nucleus displays a network of finely interlacing fibres. This network takes the dye colour deeply, and is therefore known as the chromatin of the nucleus. Weismann has taught us to regard it as the bearer of hereditary characters. Just beside the nucleus-in the large majority of cases-is a much smaller speck which is called the 
centrosome, and which apparently plays an important part in initiating the phenomena of cell-division.

Now it is beyond reasonable question the nucleus that is the essential part of the cell. The rest of the cell body has probably no more than a nutritive function. The changes in the nucleus which precede, accompany, and succeed the act of reproduction must later be described. But we may be permitted here to indulge in certain abstract considerations as to the intimate structure of the nucleus. We have already noticed the existence of a special portion of the nucleus which is readily stained by suitable dyes, and which is therefore called the chromatin. Every division of this and every other cell of any of the higher animals and plants is initiated by the breaking up of the nuclear chromatin into a number of separate rod-like bodies known as chromosomes. When these chromosomes are examined by the microscope, after treatment with suitable dyes, they are found to contain a number of smaller bodies, each of which must be regarded as a complex structure, "possessed of a historic architecture that has been elaborated slowly through the multitudinous series of generations that stretch backwards in time from every living individual." These minute bodies, or microsomes, cannot further be resolved by the microscope, but Weismann assumes that each of them in its turn consists of a number of still smaller bodies, which he calls determinants. He has his own names for the larger units, but it would be of little profit to quote them. The concept of determinants, however, is worthy of note, for Weismann argues that these 
are the structures of the germ-plasm which determine the characters of the adult organism, and it will later be of great importance to inquire as to the influences which any adult organism ean bring to bear upon the determinants of the reproductive cells which it bears, and by which it is destined to reproduce itself. But Weismann regards it as necessary, and with justice, to assume that even these determinants are not the ultimate living units. These hypothetical constituents of each determinant he calls biophores. They are the ultimate living units. It is not inconceivable that they may be identical in all living things.

Now Weismann is by no means the first or only biologist to postulate the existence of the specialised living units which he calls determinants. They have received at least a dozen different names from as many biologists during the past forty years. But in point of fact the originator of this conception was a student who approached biology from the outside. It is in Herbert Spencer's "Principles of Biology" that this idea is first to be met, long before we had attained to our present extended knowledge of the reproductive process. Furthermore, the Spencerian conception has gained little if at all from the efforts of the many workers who have since adopted it. Spencer saw that, on the one hand, the cell must be regarded as the morphological ${ }^{1}$ unit of living organisms. On the other hand, there must necessarily be a chemical unit, consisting of the simplest combination of molecules capable of displaying life.

1 Morphology is the science of form in living things. We owe the term to Goethe. 
This obviously corresponds to the biophore of Weismann. Such a unit would be common to all forms of living matter : it would have no specific characters. But if we consider the phenomena of repair-as in the growth of a lizard's leg after amputation, or in the development of a begonia from a leaf-fragment -we note the existence of a property which, in the case of repair of damaged crystals, is called polarity. Thus we may use the term organic polarity, or polarity of the organic units, to signify the proximate cause of the ability which organisms display of reproducing lost parts.

Spencer, therefore, supposed that the chemical units combine into units immensely more complex than themselves, complex as they are; and that in each organism these physiological units produced by this further compounding of highly compound molecules have a more or less distinctive or "polar" character. Obviously the phenomena of repair, which led Spencer to this most important conception, are indistinguishable in principle from any other case of heredity. If, then, we desire to track down to its hiding-place the ultimate material structure to which all the phenomena of heredity and variation must be referred, we find ourselves satisfied with the physiological unit of Spencer, re-named "gemmule," "plastidule," "determinant," and I know not by how many other terms. Recalling our study of the typical nucleus, we remember that its chromatin is really a collection of chromosomes, in which minute parts (microsomes) may be detected. Where the microscope fails us, theory steps in, and argues that these microsomes 
must consist of the physiological units postulated by Spencer.

Much space has been spent on this subject : firstly, because it is satisfactory to correlate theory with actual structure, so far as is possible; secondly, because it is plainly necessary that we should pursuc our study of the nucleus to the very last limits; and finally, because this great conception of physiological units has lately acquired a new importanceclearly anticipated by its originator-in relation to the remarkable theory of variation which traces its origin to the work of the Abbé Mendel forty years ago, but which has only within the last year or two taken its place as one of the most important of the constructive efforts of modern biology. ${ }^{1}$

It will now be necessary for us to study the reproductive cell, not in the abstract, but, so to speak, in situ, as an actual structure found, in given conditions, in all but the lowest animals and plants. So far as is possible, we must make our study of heredity a study of observed facts. The less we talk about "forces" and the more about positive entities and sequences that can be actually observed, the more likely are we to reach conclusions that will reward our labours. Fortunately, we live to-day not in the dawn of embryology, which is now, despite its difficulties, an astonishingly luminous and conspicuous science.

One further note may be made. At first sight it may seem almost incredible that a heritable organisation of great complexity can find its physical basis in a microscopic ovum and in a spermatozoon which

${ }^{1}$ See Chapter VII. 
may be only $\frac{1}{100000}$ of the ovum's size. But, as Thomson observes, "it may, however, be recalled (1) that the physicists report that the image of a Great Eastern filled with framework as intricate as that of the daintiest watch does not exaggerate the possibilities of molecular complexity in a spermatozoon, whose actual size may be less than the smallest dot on the watch's face; (2) that in development one step conditions the next, and one structure often grows out of another, so that we are not forced to stock the microscopic germ-cells with more than initiatives."

\section{CHAPTER III}

\section{THE FACTS AND FUNCTION OF SEX}

WHEN we leave the lowest animals and plants and consider the many-celled organisms we come upon the fact of sex. We find that multicellular organisms give rise to special reproductive cells, or gametes, one kind of which is produced by female organisms and another by male organisms. The former are called macrogametes and the latter microgametes (i.e. large and small gametes). The older terms applied to these cells in the animal kingdom are ova and spermatozoa. These germ-cells, or gametes, are highly typical and representative living cells, having the structure already described. They, or rather their nuclei, form "the material basis of inheritance"; and it is to them that the scientific study of heredity constantly refers us. The first question we must ask ourselves is as to the origin of these germ-cells. 
Whence do they come; what is their precise relation to the individual who bears them? This question and others connected with it logically precede any discussion as to the meaning of the fact that these gametes are of two kinds, male and fomale. It is only in the latter half of this chapter that we shall need to consider this matter. For the present we can completely ignore this sexual difference, and need discuss neither the contrasting characters of the two kinds of gamete, nor the mode of their union, nor the function served by their differentiation. These fascinating matters will be intelligible only when we know exactly what the gamete is and whence derived.

The older fashion of expressing the facts - a fashion perfectly just - was as follows. Consider the single cell from which any of the higher animals or plants is developed. (Later we shall see the origin of this cell.) It divides and divides and ultimately forms a complete organism-a bird or a man or a tree. But certain of the cells formed by these many divisions have a special function. They are kept apart in a particular portion of the organism; and they give rise to cells which do not serve the individual, or, in a sense, form any part of its structure, but which are ultimately shed and will give rise to new individuals, after union with similar cells of the opposite sex.

This is a true account; but the facts may be expressed in a much more significant fashion. I will employ the words of Professor Arthur Thomson:-

"From another point of view it may be said with equal accuracy that the fertilised ovum [i.e. tho 
single cell from which all the higher animals and plants are developed] gives rise in development to two sets of elements - to the somatic cells [somathe body], which become differentiated into the various tissues of the body, and to a lineage of nonspecialised germ-cells, some of which will eventually be separated off to begin a new generation."

Here we have an idea of cardinal importance. Ideally stated, the sequence-actually observed in inany animals - is as follows:-The germ-cells and the body-cells grow up side by side. The germ-cells are shed and give rise again to a new body and to their own undifferentiated descendants, which that new body temporarily shelters. The germ-cells are "immortal"; the individual is merely a temporary host which shelters a few generations of the germcells, whose unbroken continuity constitutes the race. Plainly the likeness of daughter and mother begins to be intelligible. The germ-cells of the mother-which will develop into her daughter-are directly continuous with the cells which gave rise to the body of the mother. "As the sex-cells in an offispring are thus genetically continuous with [i.e. directly derived from] the parental sex-cells which gave rise to it, they will in turn develop into organisms like the parent-a conception fundamental to an understanding of inheritance and development." On this theory of Weismann we must regard each individual as merely the temporary host of the continuous line of germ-cells which constitute the race.

Now in many of the lower animals the actual unbroken sequence of the germ-cells, from one generation to another, can positively be detected. 
But in higher animals, and notably in most plants, the reproductive cells cannot be recognised until the development of the organisin is considerably advanced. In such cases, then, it is impossible to demonstrate any continuity between the germ-cells of an individual and the germ-cells of its parent. But Weismann has shown that it is not therefore necessary to abandon the invaluable concept of continuity. He very reasonably assumes that the essential part of each germ-cell is not, for instance, the cell-membrane, or the cellular shape, but a particular kind of living matter-the germ-plasm. He supposes, then, that in the development of each individual a portion of the germ-plasm contained in the parental ovum "is not used up in the formation of the offspring, but is reserved unchanged for the formation of the germinal cells of the following generation." There are grounds for believing, as we shall see, that the chromatin of the nuclear network represents this germ-plasm. Though there is not always continuity of germ-cells from generation to generation-as there demonstrably is in many animals -there is always, in all the animals and plants which display this mode of reproduction, a "continuity of the germ-plasm."

This phrase must be remembered. It expresses a theory of the very highest importance; it is supported by a large amount of evidence, and is positively contradicted by none; ${ }^{1}$ it illuminates all our conceptions of inheritance; and the inferences from it are of the first importance in regard to the great controversy as to the inheritance of acquirements.

1 See Chapter IX. "The Theories of Heredity." 
If the germ-plasm is continuous or immortal, then the individual body does not produce it, but is its host. Hence we are led to inquire into the relations between the one and the other. Does the germ-plasm affect the body that carries it? Does the body affect the germ-plasm? The second of these questions will later be considered. The first is not material to our subject.

Let us now recall the fact that the germ-cells, or gametes, are male and female, for this is evidently a fact of very great importance. But it is not an essential fact nevertheless, for we find that the female gamete may develop and give rise to an individual without the interposition of the male. As this is the simpler case it falls to be considered first.

Reproduction by means of a single (female) germcell is called parthenogenesis, the nearest English equivalent of which is virgin-birth. This development of the female gamete without fertilisation by the male is found in many very lowly groups of the animal kingdom. Furthermore, it can be initiated by artificial modification of the environment of the ovum. Our business here, however, is to discuss this matter only in so far as it bears on heredity. If, then, we consider all the known cases of natural parthenogenesis, and all the successful attempts to induce parthenogenesis, what do we find as to the occurrence of heredity and variation? The case is simpler than that of bi-parental reproduction, and should be more intelligible.

Our concept of the "continuity of the germplasm" fully prepares us to understand the fact of heredity in cases of parthenogenesis. We have 
already seen that heredity is inevitable in the onccelled animals and plants; but Weismann's idea of the germ-plasm as continuous and the individual as merely its temporary trustee leads us to look upon heredity as equally inevitable, even in the case of the multicellular organisms. Now where, as in parthenogenesis, there is no complication, the new individual arising from the unassisted ovum of the old, we might reasonably expect heredity to be very exact and variation either absent altogrether or very slight. In accordance with his theory of the function of sex-immediately to be considered-Weismann taught that parthenogenetic species do not vary, cannot vary, since it is tho intermingling of sexual cells in bi-parental reproduction that, as he averred, gives rise to variations.

This matter has, therefore, been carcfully studied of late years, and it is now possible positively to deny the contention of Weismann. Variation occurs abundantly even in asexual and parthenogenetic reproduction. This is a fact of cardinal importance, and must be remembered as profoundly affecting our understanding of the cause of variations. Having carefully noted it, we are now prepared to consider the facts of heredity and variation as observed in ordinary sexual or bi-parental reproduction, which is so widely observed throughout the animal and verretable kingdoms.

In the first place, we must discuss the obsorved facts of this method of reproduction. We have noted that the gametes, or sex-cells, are of two kinds, male and female. Each of these is a complete cell; we have seen that the orum-in certain low 
forms-may actually give rise, unaided, to a new individual: and there is some evidence to show that the spermatozoon has a similar potentiality.

Now let us recall what was said as to the typical structure of a cell. We saw that the cell nucleus contains a certain stainable structure called chromatin. Now, when any cell divides, it is found that the chromatin breaks up into a number of separate portions called chromosomes. ${ }^{1}$ The number of these chromosomes is invariable for every cell of any species of animal or plant. If eight or sixteen be the number, eight or sixteen respectively are always observed in the division of any cell of any part of the body.

Let us suppose, then, that sixteen is the characteristic number of the species we are considering. The act of bi-parental reproduction consists in the intimate blending of the nucleus of the ovum with the nucleus of the spermatozoon. The result would be the formation of a new cell-the cell from which the new individual is to arise-which would contain thirty-two chromosomes in its nucleus; and at every generation the number of chromosomes proper to the species would be doubled. But a remarkable fact was discovered by Van Beneden. He found that every ovum and spermatozoon is formed by the division of what is called a mother-germ-cell (male or female). This division is of a unique character; for it results in the formation of cellsthe actual ova or spermatozoon-which contain only one-half the number of chromosomes charac-

1 Not to be confused with the centrosome, which usually lies near the nucleus. 
teristic of the cells of the species. In the case we are considering, the mother-germ-cell would contain sixteen chromosomes; but it undergoes what is now known as a "reducing division," effecting the "reduction of the chromosomes," so that the actual ovum or spermatozoon contains only eight chromosomes in its nucleus. When the nucleus of the spermatozoon and that of the ovum unite, the eight are added to the eight, and there is formed a new cell whose nucleus contains sixteen chromosomes again. From this cell arise all the cells of the body of the new individual, and each contains sixteen chromosomes, as did those of the body of its parent. These are observed and verified facts. 'Thus Huxley was right in his prophecy of 1878: "It is conceivable, and indeed probable, that every part of the adult contains molecules derived both from the male and from the female parent; and that, regarded as a mass of molecules, the entire organism may be compared to a web, of which the warp is derived from the female and the woof from the male." "What has since been gained," says Professor E. B. Wilson, "is the knowledge that this web is to be sought in the chromatic substance of the nuclei, and that the centrosome is the weaver at the loom."

Reasoning upon these facts, Professor Weismann

${ }^{1}$ A wholly new importance has quite lately been conferred upon this subject by the researches of Professor Farmer and Messrs. Walker and Moore. They have made the most important discovery that the cells of all malignant tumours - cancers and sarcomasexhibit a mode of division similar to that of mother-germ-cells. This goes very far to explain the peeuliar properties of malignat cells, and sets ns upon the right line for the complete explauation of malignant tumours. 
constructed a most ingenious and plausible and reasonable theory in which most of us have fully believed until recent times. The theory was that the sole cause of variations in all organisms save the very lowest is the intermixture of two somewhat dissimilar germ-plasms in the act of bi-parental reproduction. Observe that each gamete loses half its chromosomes, and the new cell formed from the two thus contains only a portion of the elements of each. The natural supposition was that there is a germinal selection of parental characters; some are taken, others left: and hence the new individual must vary from either of his parents, and need by no means necessarily "strike an average" between them. In other words, the function of sex is the production of variations; and the known facts seem to afford a ready explanation of the manner in which such variations arise.

Nevertheless, this most satisfactory and consistent theory must be totally repudiated. It is not enough in science, though it has always sufficed in metaphysies and in theology, that a theory be selfconsistent and logical. The contention of science is that the theory must be consistent not merely with itself, but also with the facts. We may remember Huxley's joke as to Spencer's idea of a tragedy: "A deduction killed by a fact." That is the irremediable accident that has befallen Weismann's explanation of the origin of variation and the function of bi-parental reproduction.

In the first place, it is found, on à priori mathematical grounds, that the effect of amphimixis-as Weismann calls the process of nuclear conjugation- 
should be rather regression to the racial average, or mean, than "progressive variation" from it. Agrain, it is found, as we havo already seen, that parthenogenetic and asexual reproduction are accompanied by abundant variation, though, on the theory of Weismann, there should be none whatever in such cases. Further, the biometricians-the new school of biologists who study the facts by the most rigid mathematical methods-have shown that, in general terms, the degree of resemblance between individual structures sexually produced and between individual structures asexually produced ${ }^{1}$ is the same: a fact which "renders it impossible to accept Weismann's view that one of the results produced by the difterentiation of animals and plants into two sexes is an increase in the variability of their oftspring." Further, the variation of parthenogenetically produced "brethren" amongst one of the Aphides and the Daphnia is found to be not dissimilar to that observed as the result of sexual reproduction. And measurements of a very lowly animal, the purumocium, in which sex has not been evolved at all, point to the same conclusion, viz. that, as Karl Pearson says, "Variability is not a product of bi-parental inheritance.... Whatever be the physiological function of sex in evolution, it is not the production of greater variability." Or, to quote the actual words of Mr. Archdall Reid, from whom I have taken the previous quotation: "Though nearly all biologists have supposed that progressive ${ }^{2}$ variation, and there-

1 See p. 45.

2 It may here be noted in anticipation that progressive and regressive are terms applied to variations accordingly as whether they tend away from or back to the type of the species. There is no moral significance in the terms. 
fore [organic] evolution, is largely due to bi-parental reproduction, there is, in fact, in the whole range of biological literature not one iota of evidence which supports that view. Men, as in so many instances, have accepted a dogma without proof, and have held it without inquiry."

What, then, is the function of sex in relation to heredity? That there is a function we can scarcely doubt; for though we know other uses for sex, as in human life which is incalculably widened thereby, it is not possible to explain the earlier stages of sex by reference to any future advantages, moral or social or other, such as we now enjoy.

We have already found that the exceedingly plausible and attractive theory of Weismann is untenable. If bi-parental reproduction is not a cause of variations, it must nevertheless bear some relation to them. Knowing what we do of the manner in which sexual cells unite to form a new individual, it is inconceivable that sexual reproduction has no relation to heredity and variation.

The answer appears to be that bi-parental reproduction is a means of preserving the racial type. The true answer is exactly the opposite of that given by Weismann. As this subject is more adequately and recently considered by Archdall Reid than by any other writer, I will quote largely from him in considering it. But here let me make an observation of my own. In my opinion, Mr. Reid has conclusively proved that bi-parental reproduction, by "planing away useless variations," "contributes to the stability of the species." Now a school of observers -Professor Karl Pearson and his followers-who 
study biological problems from a standpoint of their own, and who have frequently disposed of various hypotheses widely held, have lately devoted their attention to the facts of sexual selection, ${ }^{1}$ and, on this occasion, have gone far to confirm and supplement the conclusions of Darwin. They have shown that, in all cases hitherto examined, there is a principle of homogamy, the mating of like with like. It hardly needs saying that this observed fact of sexual reproduction consorts completely with the view that amphimixis is a means of ensuring the stability of the species. The discovery of the fact of homogamy is absolutely incompatible with IVeismann's interpretation of amphimixis, but most signally confirms this new interpretation of the facts of sex, which has been reached by quite another route.

Let us now make note of Mr. Reid's chief points; previously reminding ourselves of the meaning of the terms progressive and regressive as applied to variations. We have seen that amphimixis is not a cause of progressive variations. On the contrary, there is inuch evidence which shows that " bi-parental reproduction tends to eliminate the characters in which parents differ, and to leave unaffected those in which they agree." It is a matter of common observation that exceptional peculiarities of parents tend to disappear. But if both parents are tall and dark, say, or short and fair, these variations tend to be perpetuated by amphimixis. There is no evidence that bi-parental reproduction is connected with progressive variations as cause and effect; whenever it

1 This very important subject is dealt with in Chap. vi. of the volume on "Organic Evolution." 
acts at all as a cause of variations, they are regressive and not progressive: back to the type and not away from it.

When precise experiments are made, it is found that the mating of different varieties or species always tends towards great reversion-not to the immediate ancestry, but to the remote ancestral form. All the special characters tend to disappear. "The ancestral form common to both varieties, even if it be separated from the crossed descendants by thousands of generations, tends to reappear." Mr. Reid quotes a very large number of instances, animal and vegetable, from Darwin, Cossar Ewart, and other observers. These might be indefinitely multiplied.

Now Mr. Francis Galton has long ago provided us with evidence and conclusions which nicely consort with the theory of the function of amphimixis which I am trying to expound. Mr. Galton studied inheritance in animals, and, very widely, in man; including in his purview moral and mental as well as physical characters. He was thus able to enounce a wellattested law or principle, which he termed "regression towards mediocrity." [His observations were confined to the higher species, in all of which biparental reproduction is universal.] Let us take, then, one or two simple instances derived from the inheritance of mind, which illustrate this principle of regression towards mediocrity. On the average, the children of a genius tend to have something less than their father's power, but yet to be above the mental average of the race. Similarly the children of the criminal tend to be less vicious than he, though morally inferior to the average man. In 
the case of physical characters, also, this principle is constantly illustrated. It is obvious that the principle is explicable in strict accordance with the theory that the function of amphimixis is to ensure stability of the type-that is, be it well noted, the type of the race, not the new and varying parental type. ${ }^{1}$ Indeed, every kind of evidence, old and new, tends to support this new interpretation of the function of amphimixis. Mr. Reid is surely justified in saying that, "Nothing in nature is more certain than that the function of bi-parental reproduction is to produce regressive variation; and nothing in science is more remarkable than that, in spite of plain, abundant, and conclusive evidence, it should so long have been regarded as the cause of progressive variations."

Hence it appears that, in every species which is sexually reproduced, there is, on the average, a greater tendency towards reversion than towards progression, a greater tendency to vary towards the ancestry than away from it; for the weight of amphimixis is always thrown upon the side of regressive variations, and always tends towards the suppression of progressive variations. Again, to quote from Mr. Reid: "Under conditions of natural selection, biparental reproduction ensures that all [organic] evolution shall be on lines of small variations, not on lines of great abnormalities."

Mr. Reid has thought this matter out with extreme completeness. He observes that bi-parental reproduction occurs invariably in all large and com-

1 The word type in biology has always a generalised meaning, though in common parlance this proper meaning of the term is frequently obscured. 
plex organisms; that is, in all organisms that are apt to vary uselessly in a great number of ways. Now animals are more complex than plants, and therefore have a greater need for regressive variations. Hence it is that, while plants are not infrequently self-fertilised, animals, save in a very few lowly cases, are not. He concludes his remarkable chapter by saying that bi-parental reproduction plays exactly the same part in selecting regressive variations that natural selection plays in selecting progressive variations. Bi-parental reproduction, indeed, is only another name for bi-parental selection. It is almost as important a fact in evolution as natural selection; though we must remember that it is to natural selection that the evolution of sex must ultimately be referred.

It will now be desirable to pass from the methods recounted in this chapter, methods mainly of actual observation by the microscope or other means, to a totally different point of view. Thereafter, perhaps, we shall be able to see that some conclusions at any rate are to be reached by widely diverse methods; and this will constitute a high presumption in their favour. Only after the reading of the next chapter can we safely proceed to the more difficult and important part of our subject. 


\section{CHAP'TER IV}

THE BIONE'TIC STUDY OF HEREDITY

THE biometricians are a comparatively young but very important school of biologists, whose founder is Mr. Francis Galton, Charles Darwin's first cousin, and whose foremost adherent is Professor Karl Pearson, to whom we owe the term biometry, or biometrics. The characteristic of these workers is that they study large numbers of individuals, or individual characters; that they express all facts with the greatest exactness possible; that they consistently employ mathematical methods in all their work; and that they excel in the detection of fallacies. Indeed they approach biological questions with a unique equipment in mathematics and logic.

A large number of conclusions of very various kinds already stand to the credit of the biometricians. In this chapter I intend to note the more important of their researches which bear directly upon the problems of heredity and variation. It is, of course, a fair criticism that one should consider these inquiries each in strict relation to the subject of which it treats; but, on the other hand, the distinctive peculiarities of the biometric method may be held to justify this arrangement; and the reader will find allusions to the work of this school whenever it bears directly upon the various subdivisions of this book. It is necessary to remember that the science of heredity is yet inchoate. The attempt to 
reconcile the conclusions of every school of workers would therefore be not only futile, but premature. The writer is thus compelled to choose some mean between the impossible ideal of presenting a complete account of an incomplete science and the very unappetising device of stating, in isolated or mutually contradictory chapters, the conclusions of all the different groups of workers in this field. The biometricians, however, with their distinctive method and their complete independence from all save mathematical preconceptions, do very definitely demand this kind of treatment.

The main object of this school is to treat the processes of evolution quantitatively. When we use terms like variation and selection, the biometricians demand exact measurement of them: relative, of course, but still exact. It is of no use to us, they say, to be told that an organ is variable; we must know how it varies in a thousand individuals. It is of no use to tell us that a race is long-headed; we must have exact measurements of the cephalic index in a thousand individuals of that race. . . . Of course it is obvious that a very large number of biological statements are in their essence statistical. The biometricians have spent much labour upon the critical examination of these statements. Indeed it may be said that biometry is the application of the methods of the "higher statisties" to biology. Workers in many fields are beginning to discover that in the absence of mathematical training they are incompetent justly to appraise any of their statistical or quantitative results. It is thus a most satisfactory sign of the times that medical men, for instance, 
should now be sending their observations to the biometricians for analysis and criticism. The readers of the British Medical Journal have greatly profited by the publication therein of various papers by Professor Karl Pearson, dealing with such diverse matters as the inheritance of insanity and the value of anti-typhoid inoculation. It is now becoming evident to all thoughtful students that no quantitative or statistical observations, whether dealing with heredity or any other subject, can be regarded as complete until they have been submitted to expert mathematical criticism. 'There is no questioning the dictum of Kant, that the completeness and validity of any objective science is proportioned to the degree in which it is informed with mathematics. Sometimes, when the student wants a laugh, he tries to picture the results of submitting the crude and ludicrous arguments for and against "Fiscal Reform," to the eriticism of the mathematician. But "let that pass."

Ignoring for the nonce the critical and corrective services of biometry, we may note the chief of those constructive efforts which already stand to the permanent credit of its youth. The tirst of these is now known as "Galton's Law." Many years ago Mr. Galton devoted himself to the exact study of "huminn faculty" in relation to heredity; and also to the sutudy of the inheritance of physical characters in certain of the lower animals. He collected and analysed an enormous number of data as to health, eye-coluur, stature, and artistic faculty in several generations of some hundred and fifty distinct families. Later he was able to study the records of the colours of a 
large pedigree stock of Basset hounds (dwarf bloodhounds) belonging to Sir Everett Millais. He found that the human and canine data, widely various as they were, could yet be expressed in an exceedingly simple generalisation which he called the law of ancestral inheritance. In all probability this law may prove to be universally true of bi-parental reproduction. There is a quite valid sense in which we regard inheritance as dual, half-paternal, half-maternal. But it is plain that the same applies to the inheritance of each parent, and so on ad infinitum. Hence the inheritance of each individual is not dual but multiple, and Mr. Galton has proved that it is actually capable of exact mathematical expression. But before we see what this is it is necessary to state, as clearly as may be, that Galton's Law deals with races and generations, not with individuals. In the discussion of the principles of heredity, or indeed of any biological generalisation, it seems impossible to bring home to some people the idea that they are generalisations, not "particularisations." The objections of such people imply a confusion of thought such as that which would suppose the statement of a cricketer's batting average as twenty to mean that whenever he went to the wickets he made twenty runs, never more, never less. The law about to be stated is an average, and much less to be disproved by the quotation of single instances than the statement of the batsman's average is disproved by the observation that on such and such an occasion he made a "duck" or a "century."

Galton's Law may thus be stated:- "The two parents between them contribute on the average 
one-half of each inherited faculty [or chiricter], each of them contributing one-quarter of it. The four grandparents contribute between them onequarter, or each of them one-sixteenth, and so on, the sum of the series, $\frac{1}{2}+\frac{1}{4}+\frac{1}{8}+\frac{1}{18}+\&$ e., being equal to one, as it should be. It is a property of this infinite series that each term is equal to the sum of all those that follow." The opinion of Professor Karl Pearson, in which there concurs a biologist of so different a school as that to which Professor J. A. Thomson belongs, is that Galton's Law expresses in one simple generalisation the ultimate result of all the complex factors in heredity.

Certain comments fall to be made upon this law. We have already seen that, in accordance with Weismann's conception of the "continuity of the germ-plasm," the line of descent is not really from individual to individual, but from germ-cell to germcell. Plainly, however, Galton's Law deals with individuals. But Mr. Galton has himself pointed out that the independent establishment of this law by no means involves the rejection of Weismann's conception. On the contrary, the two are compatible and complementary. For though Galton's Law deals ostensibly with individuals, we now know enough of the origin of the individual to see that it may always be taken as fairly representative of its own grumcells, to which, indeed, its relation is not parental but fraternal; for the one primal cell may be conceived as giving rise by its divisions on the one hand to the individual, and on the other to his germ-cells. But even more significant is the manner in which Galton's Law corresponds with the observed facts of nuclear 
change prior to the union of the male and female gametes. For we have seen that one-half of the nuclear chromatin of each gamete is thrown aside prior to the fusion of the two nuclei. This obviously corresponds exactly with Galton's assertion that the two parents between them contribute one-half of the total heritage of the offspring. Thus the facts of nuclear change in the process of gametogenesis (i.e. the formation of the gametes from their mother-cells) as observed by the microscope in the case of various very simple animals, precisely correspond with a mathematical formula derived by Mr. Galton from the study of the inheritance in man of such things as "artistic faculty." Surely we are entitled to regard Galton's Law as demonstrably true.

Its importance can scarcely be overestimated. It is the theoretical basis upon which Galton and Pearson have constructed a whole series of important conceptions that have already served the science of heredity. It has been shown to be more comprehensively true than even its discoverer recognised. It is even found to survive the criticism passed upon it by the recent experimental study of variation in plants and other organisms. But whilst we freely recognise the importance and value of this law and its elaborations, we must not delude ourselves with the idea that it leaves nothing to explain. In a certain sense, perhaps, Galton's Law, as extended by Pearson, may be said to "render the whole theory of heredity simple, straightforward, and luminous"; but it is evident that the author of this opinion was, for the moment, taking a very narrow view of the problems involved in the means by which Galton's 
Law works itself out. Nevertheless we inust adinit that, from the special standpoint of the biometrician, this law must appear to be all that Dr. Vernon thinks it.

Most valuable results have followed the work of the biometricians upon the variableness of such structures as leaves, hairs, or scales, which aro repeated in the body of the same individual organism. Without detailing the highly complex methods employed in this study, and without noting certain tentative results which may prove to be of great value, we may pass at once to the bearing of these studies upon the facts of bi-parental reproduction. The reproductive cells must be regarded as "serial homologues," the name applied to structures repeated in the body of one individual. Now the comparative study of brothers is plainly a means by which we can study the variableness of the reproductive cells of the father. But in the study of the production by a man of repeated sex-cells, represented by his sons, there is the obvious complication that the sons are derived from their mother as well: the case is hardly parallel to that of the repetition of leaves (which are not sexually produced, of course) on the loody of a plant. But Pearson has made the very important observation that the variableness of human children "obeys the same law as that of other repeated structures." 'These biometric observations are of great value in enabling us to reject Weismann's theory of the function of bi-parental reproduction as a cause of variations: for they unquestionably show that no increase of variableness is associated with this method of reproduction. Let us clearly understand 
the argument. Sex-cells and leaves (for instance) are structures repeated in the same individual. We measure the variableness of the leaves, and then that, not of the sex-cells, indeed, but of sexually produced children-whose variableness represents that of the father's sex-cells plus so much variableness as may be due to the fact that each child is the product not of the paternal sex-cell only, but of that and another. But it is found that the correlation between the children thus produced is no less than that between leaves repeated on one individual plant. Plainly, therefore, the occurrence of bi-parental reproduction has not been a cause of variation.

Lastly, we may note one of the very latest results gained by the methods of biometry. The relative variability of man and woman has long been discussed. Some, regarding the matter from the physical side, have believed that woman is more variable than man. Others, considering the mental characters of the two sexes, have declared that woman is more conservative, that is to say, less variable, than man. It is man, they say, who always originates the new ways of thinking, which, in any sphere, are first stigmatised as heresy. Heresy, of course, is none other than variation in the realm of thought, and is as necessary to progress in the realm of ideas as physical variation in the realm of anatomy.

But the biometricians have clearly shown-confining themselves, as one might expect, to the physical side of the question-that no difference between the variability of man and woman can be detected. It might indeed have been anticipated $\grave{a}$ prior $i$ that no correlation between sex and variability would be 
discovered. For, whatever be said to the contrary, the two sexes, from the biological point of view, are strictly equal and complementary.

\section{CHAPTER V}

\section{THE FACTS AND LAWS OF VARIATION}

A CHAPTER is formally devoted to this subject simply for the sake of emphasis. The reader has already seen that in discussion of strict correlatives, such as heredity and variation, the two cannot be dissociated, since each implies the other. Thus in the preceding and following chapters we find as much to say of variation as of heredity. But the emphasis of a separate chapter may be of use in enabling us fully to appreciate the conclusion which has been reached by the $\grave{a}$ posteriori study of variation.

We have already argued that certain current ways of looking at variation are untenable. Not concerning ourselves with the detailed facts that may be observed, we have argued deductively from certain principles that variations cannot be regarded as arbitrary or as outside the law of causation, or as incalculable or as accidental lapses on the part of the law of heredity, and that, as believers in the Uniformity of Nature, we must hold to our view in spite of appearances.

But the fact here to be insisted upon is that "appearances" are for us and not against us. Wo find that when we come systematically to study the facts of variation, they are not arbitrary or incalcul- 
able. We find, on the contrary, as has been illustrated in the previous chapter, that these facts, though admittedly incalculable for the individual, are yet capable of mathematical expression, often of the simplest, when we consider large numbers of individuals. Similarly the physicist, be he a Kelvin, is unable precisely to predict the size and course of all the fragments produced by an explosion. Yet he knows that the laws of motion and gravitation and chemical combination and gaseous pressure are observed, and his knowledge is not affected by the circumstance that his limited powers do not suffice for precise prediction in such a case; nor would he regard with anything but sympathy the writer who should say, "Well, I am content to conclude that, since no one can predict the course and weight of even one of these fragments, either there are no laws in the matter, or else they are wholly unknown." This is precisely what is said by the critics in relation to the study of such subjects as variation; and the criticism is as worthless in one case as in the other. When variation is studied on a sufficiently ample scale-in accordance with the general principles of $\grave{a}$ posteriori reasoning, for the more numerous the foundation-facts, the more secure and comprehensive must be the generalisation erected upon themwe find the facts are capable of being expressed in certain general propositions, such as are commonly called laws in scientific writings.

There is a fundamental distinction between a law and a cause, as the case of gravitation suffices to illustrate. Nevertheless, we are surely entitled to assume that the occurrence of a law, i.e. of a natural 
order, implies a natural cause. In point of fact, we all do make this assumption. We do not pray that two days shall follow one another without an intervening night, for the invariable sequence of night and day has caused us to assume that it lies within the sphere of natural causation. Similarly the "Book of Common Prayer" still contains a form of prayer for rain, meteorology not being sufficiently advanced to enunciate such laws as would convince unthinking men that the weather, also, is determinerl by natural causation.

Now, in the case of variation, it may similarly be argued from the existence of the laws which the Mendelians, the biometricians, and others have discovered that this phenomenon, like all other's, is within the sphere of natural causation. It is, then, submitted that $\grave{a}$ priori considerations and $\dot{c}$ posteriori considerations (viz. the fact that it is possible to enunciate laws of variation), lead alike to the same conclusion, that the causes of variation are to be found in the natural order of things. So certain is the evidence of these complementary lines of reasoning that our faith in their common conclusion is not shaken by the circumstance that, as we shall see, the causes of variation are still somewhat obscure.

\section{CHAP'TER VI}

\section{THE ORIGIN OF VARIATIONS}

IT is of the first importance that we should have an understanding of the causes that produce variation. It is so, not merely by reason of the 
frequency of variation, or the fact that it so constantly accompanies heredity, but pre-eminently because of the supremely important rôle of variations. As Bateson says of heredity and variation: "Every one knows that, somewhere hidden among the phenomena denoted by these terms, there must be principles which, in ways untraced, are ordering the destinies of living beings." Without variations, natural selection would have no material upon which to work. Even when we limit the term, as is done throughout these chapters, to mean what are sometimes distinguished as blastogenic variations, those true variations which have their seat in the germ, we must recognise that without variation there could be no evolution.

What, then, is the origin of true variations: "spontaneous" or "germinal" or "blastogenic" variations?

We are long past the days when it was possible to speak of heredity and variation as opposing "forces" or "principles." These are good words in their place; out of their place they merely cloak ignorance. Also, we cannot be satisfied by explaining variation in accordance with that amusing piece of nonsense known as the Bathmic ${ }^{1}$ theory of organic evolution, which attributes it to an "inherent adaptive growth-force." Nor have we any use to-day for the hypothesis that variations are unique amongst phenomena in being outside the law of universal causation; that they are directly due to the designing volition of a Divine Person. If all rational explanations fail us, we must not content

1 From the Greek bathmis, a step. 
ourselves with the adoption of vague but imposing phrases, nor seek to darken counsel by words without knowledge.

In the case of the lowliest organisms, such as, for example, the animal Amoba, or the vegetable bacterium, we can draw no distinction between the germ-plasm and the body-plasm. Any acquirement, such as the exaltation of virulence due to the passage of disease-producing bacteria through the body of a susceptible animal, must be a cause of variation; for the descendants of such bacteria are certainly more virulent than were their ancestors before their experience of this suitable environment.

But the problem before us is the origin of variations in all the higher animals and plants, which are propagated by bi-parental reproduction.

In the first place, we find ourselves compelled to reject certain suggested causes of variation in these organisms. We find that, even assuming the acquirements of the individual so to alter the germ-plasm on occasion as to produce true variations, yet this transmission of acquirements is totally inadequate to explain the great majority of cases of variation.

Even the most recent opinion of Weismann (which is in some measure a concession to his critics), that the germ-plasm, on rare occasions and to a small extent, may be so affected by its sumoundings as to give rise to variations in the offispring, is almost infinitely far from being tantamount to an allequate explanation of the eause of variations.

We find, again, that it is impossible to explain variation by the assumption of a direct action of the external environment (by which clumsy phrase I 
mean the environment other than the individual body) upon the germ-plasm, such an assumption being unsupported by evidence.

Yet a third suggestion, as we have seen, must be rejected in consequence of the work of the last decade. We must reject as incompatible with the facts the theory of Weismann that the great cause of variations is amphimixis or bi-parental reproduction. We must reject this theory despite its apparent adequacy and its attractiveness, and despite the fact that, having rejected it, we are almost at our wits' end for a better.

Let us see how the difficulty is met by Archdall Reid, after his brilliant exposition of the evidence which has led to the rejection of Weismann's theory. $\mathrm{He}$ declares that spontaneous variations are due "undoubtedly to an inborn tendency to vary, a tendency that is inherent in the germ-plasm of every species of plant and animal." Certainly Mr. Reid does not offer this answer without an attempt to explain the origin and cause of this tendency, but after the most careful study of his speculations, ${ }^{1}$ I confess that they afford me no satisfaction, and I cannot persuade myself that they are worth quoting. When we come to the summary of the first section of his work, we read:-

"IV. A progressive variation constitutes a deviation from the parental and ancestral type, which, speaking generally, is in the direction of increased magnitude and complexity. It results from the complete recapitulation of the parental development plus an addition." 
Which raises the natural query-Whence the addition? The addition is the essence of the variation; it is the variation. Hence the last sentence quoted, which professes to explain the cause of the variation, does not seem to me to fulfil its promise. Surely when Mr. Reid wrote "It results from . . . ." he meant "It consists in . . . ."

If next we consult the admirable article on heredity recently contributed by Professor Arthur Thomson to the Encyclopredice Medica, we find no discussion of the cause of variations, save in so far as his cautious rejection of the doctrine that acquirements are transmitted (i.e. are causes of variation) answers to this description.

Next we may hopefully turn to the article, "Variation and Selection," recently written by Professor Weldon for the new volumes of the Encyclopectia Britannica. But again we are disappointed. True, Professor Weldon cites the evidence which disproves Weismann's theory that bi-parental reproduction is the chief cause of variations; but the only positive statement as to the true cause of variation is that, "the production of a regular series of variations, under given environmental conditions, is a property of species as constant as the production of typical individuals." This is an exccedingly important proposition, but it does not satisfy us who are seeking to know the cause or causes of variations. The author of the new article, "Embryology," in the samo work, who is no less a person than Hans Driesch, inclines to the theory of Weismann. Dr. Chalmers Mitchell, the author of the new article, "Evolution," clearly recognises the distinction between 
formulating laws of variation and explaining the causes of variation, but he gives us no further help.

Let us now return to Weismann himself, and see whether he has any further light to throw on our problem besides that which we have already rejected - the statement that true variations are due to amphimixis. Weismann's theory of the continuity of the germ-plasm was first advanced in 1883. Ten years later, in his work, "The Germ-Plasm," Weismann explained true variations as due to the direct action of external influences upon the hypothetical "biophors" and "determinants" of the germ-plasm. The relation between the germ-plasm and their environment is nutritive, as we shall see in discussing the possibilities of modification of the germ-plasm by the body of the individual. ${ }^{1}$ Weismann supposes the constituent structures of the germ-plasm to undergo incessant changes of composition during their residence in the body of the individual, and these changes are the essential causes of variation. The immediate cause of these changes is to be found in the "inequalities of nutrition" to which the determinants are subject. Thus though it is amphimixis ${ }^{2}$ that Weismann regards as causing the constant occurrence of variations as seen in the individual, he inclines to the view that amphimixis is not the primary cause of these variations, "but that the

\section{Chapter X.}

${ }^{2}$ Amphimixis is the term applied not only to the union of the male and female nuclei in bi-parental reproduction, but also to the conjugation or union of two entire individuals, often observed in unicellular organisms. 
process furnishes an inexhaustible supply of fresh combinations of individual variations." 1

We owe to Dr. Vernon a recent and careful consideration of the evidence in favour of these two factors. Amphimixis we have already rejected as a cause of progressive variations-variations away from the specific type-though it may be a cause of regressive variations-back to the type. Dr. Vernon, however, accepts the teaching of Weismann on this point, but it is probably not necessary here to reconsider the evidence which he advances.

It is of importance, however, carefully to consider the evidence in favour of the view that the ultimate cause of variations is to be found in inequalities of nutrition acting on the individual constituents of the germ-plasm. Dr. Vernon conducted a long series of experiments on the sex-cells of the sea-urchin, known to systematists as Strongylo-centrotus lividus. The ova, or the spermatozoa, or both, were kept for varying numbers of hours in sea-water before fertilisation was allowed to oceur; and after eight days the larvæ resulting from the fertilisation were measured. It was found, in brief, that difterences in the degree of freshness of these gametes, that is to say, "inequalities of nutrition acting on the germ-plasm," had "a very appreciable effect upon the size of the subsequently developing larva." 'The effects differed markedly according as whether the female or the male gametes, or both, were stale or fresh; whence it may be inferred that different portions of the same sex-cell may also react differently to one and the

I I quote from the excellent chapter, "Blastogenic Variations," in Dr. H. M. Vernon's "Variations in Animals aud Plants." (International Scientific Series, vol. Ixxxviii.) 
same change of nutrition. The difference between male and female gametes is presumably a difference of determinants, hence the difference in the reaction of the male and female gametes is a difference of reaction, not on the part of the cells as a whole, but on the part of certain of their determinants-which is precisely in accordance with Weismann's contention. Other experiments demonstrated the existence of a seasonal variation, showing that "inequalities of nutrition" dependent on the time of year undoubtedly affect the sex-cells of the sea-urchin, which are typical of germ-plasm in general.

Various experiments of Cossar Ewart on the rabbit, and of De Vries on plants, seem also to support the view that the germ-plasm is affected by "inequalities of nutrition." But, indeed, the assertion that the germ-plasm, unlike all other living entities, is not subject to change in virtue of its converse with its environment, was quite incredible from the first.

But, since we are consulting authorities, we will do well to consider the conclusions reached by the profoundest intellect-not even excepting Aristotle's - that has ever been applied to the problems of biology. In his "Principles of Biology," published forty years ago, Herbert Spencer considered the question of the origin of variations, and it goes without saying that he did not content himself with any such petitio principii as is involved in the assumption of an "inherent tendency to vary." Spencer's discussion of the question follows closely upon his setting forth of the great conception of "physiological units," which now-under various 
aliases-plays a leading part in all theories of heredity and variation. This conception, combined with certain of the abstract conclusions reached in "First Principles," enables Spencer to account for the "spontaneous variation" of new individuals simultaneously produced by the same parent-animals of the same litter. Plainly this is the case which most severely tests any proffered explanation of the causes of variation.

Now Spencer had already enunciated a law termed by him the law of the instability of the homogeneous. In ordinary language this law may be interpreted as stating that any homogeneous aggregate necessarily tends to become heterogeneous, since its several (similar) parts are necessarily exposed to different forces, and are therefore of necessity difterently modified. Spencer illustrates this law from astronomy, geology, sociology, biology, and psychology. Now, if we apply the law of the instability of the homogeneous to the mother-germ-cell, which, by the process called gametogenesis-the genesis of gametes-divides and gives rise to the actual gametes, or sex-cells, we see that, since no two parts of any aggregate are subject to precisely the same forces, and must therefore become dissimilar, no two ova, spermatozoa, or pollen-cells, formed as they are by a process of evolution from the mother-grerm-cell, can be identical. Between them there must be "small initial differences in the proportions and condition of the slightly unlike physiologrical units." At once we see that the view of Weismann had been anticipated. The "small initial differences" in the "physiologrical units"-or "determinants"-arise in 
consequence of the fact that no two parts (e.g. physiological units or determinants) of the mother-germcell were subject to precisely the same forces. This plainly recalls the Weismannian explanation-“inequalities of nutrition."

Thus we are prepared to understand that the essence of variation is a novelty in the cell-divisions, by which the mother-germ-cell, or germ-mother-cell, gives rise to the "germ-daughter-cells," and these to the "germ-granddaughter-cells," which are the gametes, or germ-cells, themselves. This novelty is a deduction, in the pages of Spencer, from the law of the instability of the homogeneous. Forty years later we find Professor Bateson saying, in a Presidential Address to the Zoological section of the British Association (1904), that "variation is a novel celldivision": that is, a novel cell-division during the process of gametogenesis. Bateson's assertion did not depend on the validity of Spencer's deduction of 1864, but was based upon the work of the Abbé Mendel and his recent followers-work which we shall consider in the next chapter.

But even now we have not yet adduced all the reasons for looking up the pages of Spencer before passing to the consideration of Mendelism. For Spencer goes on to say, in the paragraph from which I have already quoted, ${ }^{1}$ that another fact in the link of events which determines variation is the "segregation which inevitably goes on in any mixed aggregate of units and prevents a homogeneous mean between the two parents." The existence of this segregation in the case under consideration is

1 "Principles of Biology," § 88. 
deduced by Spencer from his general conclusion, reached in $§ 163$ of "First Principles," that there must always be a process of segregation, since evolution consists in a change from the homogeneous, not to a "vague chaotic heterogeneity," but to an orderly heterogeneity. The terminology is somewhat difficult to those unfamiliar with it, but the reader is merely asked to note Spencer's arrival by deduction -i.e. reasoning from the general to the particularat the conclusion that segregation plays a part in variation, ensuring that variation-which is only a special case of universal evolution-is orderly and not chaotic; and that, in the case wo are considering, it "prevents a homogeneous mean between the two parents." In the next chapter we shall see how the Abbé Mendel reached similar conclusions as to the nature of variations by the opposite method to Spencer's, by induction-i.e. reasoning from the particular to the general-from the experimental facts which he had observed. It is not a little remarkable that Spencer's à priori reasoning, and Mendel's à posteriori reasoning, should have coincided in time. It is quite probable that on the very day when Spencer wrote the paragraphs I have quoted, Mendel had conducted experiments on peas; yet we may be almost certain that neither of them had ever heard the other's name: and science was to wait several decades before the work of the experimenter was to be brought into correlation with the conclusions of the philosopher. 


\section{CHAPTER VII}

\section{MENDELISM}

As is asserted at length in another volume, ${ }^{1}$ the theory of organic evolution was re-stated by Darwin in 1859, in a form which has stood the test of the most intellectually active decades in history. Darwin took for granted the existence of variations, and showed how animal and vegetable species might have their origin in the selection of such variations as were advantageous in the struggle for existence. This theory of natural selection is now a truth questioned by no competent and very few incompetent critics. This granted, it is seen to be a matter of prime importance for evolutionary theory, as we have already observed, that we should determine the causes of variation, and formulate the laws of variation-if such there be-as no man of science can doubt. But during nearly all these past years the subject has been almost ignored-overshadowed by the colossal controversy concerning the fact of organic evolution in general, and the Darwinian contribution to its explanation in particular. Latterly, however, the controversy ended, and ended conclusively, as all controversies about verifiable or rational matters ultimately must, and biologists were free to devote more attention to the cardinal and initial fact of variation-upon which the whole theory of natural selection is based.

Then "a curious thing happened," and it was found

${ }^{1}$ See "Organic Evolution" in this series. 
that, just at the time when Darwin's pen was shaking the world, another quiet worker was attacking the root question in Austria. The pacific Darwin had at least one champion who was a master of polemics, and his work was soon noiserl abroad. But the Abbé Gregor Mendel had no Huxley; and there was nothing particularly sensational about his leisurely but scrupulously honest and scientific observations on the mating of different kinds of peas. Dogmatic systems did not worry. themselves about peas, and Mendel did not "stagger humanity" with any assertions as to the origin of our kind. Hence it was that for just thirty years-and these, as I have said, years violently agitated about the very questions which Mendel had helped to solve-scarcely any one had heard of his name or his work. Finally, Professor Hugo de Vries, the distinguished botanist of Amsterdam, rediscovered it. He set to work to verify and amplify the Abbés all-but-forgotten experiments, which had been published in 1865 . In this country he gained an ally in Mr. Bateson of Cambridge, and now Mendelism is perhaps the most bruited sulject in the whole realm of biology. It is now beginning to appear that the Abbés leisure hours served in great measure to elucidate the causes of variation and the laws of its occurrence. He has tanght us that, as we noted in the first pages of this book, variations are not a sort of "fluke," nor the results of incompetence on the part of the "force" called heredity; but that certain variations are themselves the expression of a form of heredity. ultimately subject to the same laws and dependent on the same sequence of events. It is interesting to speculate 
how long this radically important work of an Austrian abbot in the distant 'sixties would have remained in obscurity had not De Vries possessed the patience and industry to look into it, the insight to recognise, and the ability to demonstrate, its importance.

Make Mendel's discovery simple I cannot, the facts being complex; but I must do my best. We have seen that each gamete-of either sex-is formed by a series of divisions beginning in a germ-mothercell. Now the essence of Mendel's discovery is this. The germ-mother-cell, which is about to divide and form the gametes that are to reproduce any individual in his or her descendants, contains characters derived from both the parents of that individual. These characters exist in the germ-mother-cell in opposed pairs-e.g. a character corresponding to the white pigmentation of the individual's father, and a character corresponding to the black pigmentation of the mother. When the germ-mother-cell divides so as to form the gametes, these opposed pairs of characters are split up or segregated, the black character going to one gamete and the white character to another. Thus the gametes, or sex-cells, of a grey individual are not potentially grey, but either black or white. The germ-mother-cell was grey (so to speak) like the individual, but its greyness depended on the possession of an opposed pair of characters, black and white; and these characters are segregated during gametogenesis. Observe now the result. The individuals of the new generation may be of three kinds in respect of the character of colour. Some of them will be white, since they are formed by the 
union of two white-bearing gametes, some black, since formed by the union of two black-bearing gametes, and some grey like their grey parents, since formed by the union of a black-bearing with a white-bearing gamete. But the gametes of this new grey individual will not be grey, but black or white, as before.

The discovery that variation-e.g. the birth of a black individual to grey parents-may really be a form of heredity, proceeding according to definite laws, and this statement of the working of the process, constitute Mendel's law of segregation.

Such variations as these may be called mutations, in order to distinguish their great extent. From Mendel's law it follows that we can no longer accept the old doctrine quoted by Darwin that Nature does nothing by leaps-per saltum. We see that new species may suddenly arise by the operation of the laws of heredity quite apart from any slow accumulation of variations under the influence of natural selection. As Bateson says: "The dread test of natural selection must be passed by every aspirant to existence however brief": but that expresses the totality of its power. Natural selection selects; it does not originate or create.

Space fails here for the discussion of the many facts which "Mendelism" and the "mutation theory" help to explain. What, for instance, could be more puzzling than the "limitation of heredity by sex"; the transmission of hemophilia and colourblindness, for instance, from bleeding or colourblind males, through normal females, to their male but not their female descendants ${ }^{1}$ : or the trans${ }^{1}$ See Chapter XIII. "Heredity and Disease." 
mission of a "good milking strain" by a bull, which cannot produce one drop of milk in a lifetime? Yet these and many other cases, not to mention the cases where heredity "skips a generation," can be explained on Mendelian principles. It is only necessary to postulate an intertangling of the characters in the germ-cells. Thus, the character that will develop itself as colour-blindness may be conceived as intertangled with the character that makes for maleness of sex. They are segregated together. In the female, the character making for maleness of sex is temporarily suppressed, and with it the intertangled character of colour-blindness. In her male children the two reappear together. The characters that appear in any individual are called dominant, those that remain latent, to become dominant in some future individual, are called recessive.

\section{CHAPTER VIII}

\section{REVERSION}

At least three terms suggested themselves for the title of this chapter-reversion, regression, and atavism, each of which hints at a return, through inheritance, to a type supposed to have occurred in the ancestry of the individual under discussion; or the reappearance in him of latent ancestral characters.

The word atavism we may definitely abandonespecially since we have more accurate terms to take its place. As Chalmers Mitchell points out, a great 
many supposed cases of atavism are merely cases of normal variation, as when a tall man with short parents is set down as a case of atavism because he is known to have had a tall ancestor. Other cases of so-called atavism are better called cases of reversion, of return to the ancestral type. Karl Pearson gives separate definitions of the terms atavism and reversion, but as the terms are often used interchangeably, or conversely, we may content ourselves with speaking of reversion alone. Thus when Thomson says, "what are called reversions are probably in many cases misinterpretations," he means just what Mitchell means when he says that "atavism is, in fact, a misleading name covering a number of very different phenomena."

It is scarcely necessary to multiply instances of reversion, but I may quote a typical one recorted by Cossar Ewart. The Edinburgh professor mated in pure white fantail cock-pigeon with a cross between an "owl" and an "archangel." "The result was a couple of fantail-owl-archangel crosses, one resembling the shetland rock-pigeon, and the other the blue rock of India. Not only in colour, but in shape, attitude, and movements there was an almost complete reversion to the form which is believel to be ancestral to all the domestic pigreons."

The generally accepted explanation of reversion is that it is due to the sudden activity of "latent ancestral units" ; or, in the words of Thomson, "that characters may be latent for a generation or for generations, or, in other words, that certain potentialities or initiatives which form part of the heritage may remain unexpressed "-to find expression at last 
owing to causes yet undetermined. As Thomson says, "There does not seem to be anything in this conception which is at variance with more securely established generalisations." The Mendelians have taught us how characters may become latent, or "recessive," subsequently to find expression.

There is, however, another way of looking at reversion. It depends upon an important conception which must here be briefly discussed.

The "recapitulation theory" maintains that "ontogeny"-the history of the individual-is a recapitulation, with abbreviations, and gaps, and modifications, of "phylogeny"-the history of the race. This is a conception to which immense importance is attached by Haeckel and Archdall Reid. For some years past, however, it has been growing in disfavour amongst many biologists, who are apt to declare that it is scarcely more than a misleading metaphor. This disfavour is due, I think, largely to a reaction from the excessive dogmatism and rigidity with which the recapitulation theory was formerly supported. But even if we admit, to the full, the fact that the recapitulation of its racial history by the developing individual is extremely blurred and often very partial and imperfect, there yet remains sufficient positive evidence to show that the theory is well based on facts; and there can be no question that it is most fruitful in its applications to many and various phenomena of embryology.

Now Archdall Reid correlates the recapitulation theory with the facts of reversion. He inclines to regard reversion not as due to the sudden activity of "latent ancestral units," but as simply due to the 
premature arrest of the process of recapitulation. The reverting individual is thus really an example of arrested development. It should have showed, let us say, the stages of fish, amphibian, mammal, in turn; but it declined to undertake the complete recapitulation of its racial history, and thus appears, when adult, as semi-amphibian instead of mammalian. In criticising supposed cases of reversion, Thomson says, "Often there is not the slightest attempt to eliminate the phenomena of arrested development." Reid maintains that reversion is essentially a phenomenon of arrested development; that is to say, of "incomplete recapitulation."

Here, I make no attempt to adjudicate between these rival theories, but present them both, each being plausible and each of interest. I will merely note that Reid, accepting the very recent view that, despite Weismann, bi-parental reproduction is not a cause of progressive variations, maintains it to be a cause of regressive variations, that is, of reversion to type; the said reversion being otherwise expressod as incomplete recapitulation of the racial history by the developing individual.

Here the biometricians offer us results of importance. Rejecting Weismann's theory, they maintain -as does Reid-that one of the most important results of amphimixis is the steady tendency to maintain-or, if necessary, to revert or regress tothe type. "In the tenth generation a man has 1024 tenth grandparents, and is thus the product of an enormous population, the mean of which can hardly differ from that of the general population. Hence this heavy weight of mediocrity produces regression 
... to type." This is Galton's law of regression towards mediocrity, already discussed. It follows from it that where there is much in-breeding the weight of mediocrity will be less, and the peculiarities of the breed will be accentuated. The present German Emperor might have had 4096 ancestors in the twelfth generation; but, owing to inter-marriages (i.e. in-breeding) probably had only 533. The weight of mediocrity is less, the tendency to regression less, and the distinctive characters of his race thus more likely to be preserved.

\section{CHAPTER IX}

\section{THE THEORIES OF HEREDITY}

IN this very brief chapter we may indicate, side by side, the three theories of heredity which are elsewhere frequently alluded to. By theories of heredity we mean explanations of the actual sequence of events which results in the reproduction of like by like. Of these there are but three worthy of mention.

The oldest is Darwin's theory of pangenesis, which supposed that every body-cell produces "gernmules" characteristic of it, which are somehow gathered together in the germ-cells. When these develop, the gemmules reproduce, in the body of the new individual, the characters of those cells of the parent from which they were derived. On this theory nothing could be more natural than the transmission of acquirements. But it is absolutely incompatible with the facts known to nodern embryology, 
and any one who comes to consider, for instance, the means by which the "gemmules" are to find their way to the reproductive glands, will agree that this theory offers inherent difficulties of the most furmidable character.

The second theory of heredity is expressed in the fascinating conception of Weismann-" the continuity of the germ-plasm." 'This has already been discussed. Here we merely note that it supplies a most satisfactory explanation of the fact of heredity; and that it markedly contrasts with the preceding theory in its bearing upon the belief in the transmission of acquirements. We may also note some remarkable fashions in which the theory may be expressed. If it be true, there is a sense, as Mr. Galton observes, in which the child is as old as the parent, for when the parent's body is developing from the fertilised ovum, a residue of unaltered germinal material is kept apart to form the future reproductive cells, one of which may become the starting-point of a child. Further, the theory gives a new meaning to the saying that the child is "a chip of the old block." As 'Thomson says, "Similar material to start with, similar conditions in which to develop, therefore, like tends to beget like." Lastly, note, that on this theory the daughter is really the sister of her mother.

The third and most recent theory of heredity is that of Oscar Hertwig. He denies the existence of a cardinal distinction between the germ-plasm and the plasm that goes to form tho individual body. $\mathrm{He}$ observes that in the higher plants there is widespread occurrence of tissues which have the power 
of reproduction; though these tissues belong to the individual body of the plant, and are definitely distinct from the special reproductive tissues which contain the "germ-plasm" of Weismann. Further, in many of the lower animals and plants, budding is possible in almost any part of the body. Further, there are the facts of regeneration and repair, which have compelled Weismann to introduce an extremely hypothetical and artificial sub-section into his theory of the continuity and fundamental distinctness of the germ-plasm. But the facts cited by Hertwig are intelligible if we assume that every cell of the body "contains the germinal material for every part of the body, and thus, on the call of special conditions, can become a germ-cell again." Hertwig supports his theory by very numerous and varied experiments. These appear to show that when embryonic organisms are exposed to abnormal conditions their cells can be made to undergo unusual forms of development and take on functions other than those observed in other conditions. The inference is that no particular cells are unalterably predestined for the reproductive or any other function, and that the environment can cause this or that cell, or collection of cells-according to circumstances-to devote itself to the functions of the "germ-plasm."

It is not here proposed to attempt the reconciliation of the diverse views of Weismann and Hertwig. The writer's duty is rather to note the existence of these differences of opinion. If the theory of Weismann should appear to the reader to have received undue consideration in these pages, 
since there are such formidable objections to it as Hertwig has marshalled, the only defence to be offered is that Weismann's theory does nevertheless appear to bo so well founded, and so fruitful in the deductions to be drawn from it, that we may legitimately reduce our recognition of Hertwig's criticisms to something like the proportions of the preceding paragraphs. If the reader likes his science complete and exact he must be content to ignore biology.

\section{CHAP'TER X}

\section{THE INHERITANCE OF ACQUIREMENTS}

DoubTLEss the best method of attacking the controversial subject of this chapter is to define our leading terms with all possible precision.

For convenience in practice, or for purposes of study, it is possible to isolate from the Whole, which we call the Universe, any entity or agrgregate that we please and to establish an antithesis between it and all else. The whole universe, save une atom, or one electron, or one organism, is the environment, the "milieu environnant" of that atom, or electron, or organisn. If we are to be philosophic, we must not presume to say that only certain entities or aggregates may be thus conceived. If we may select an obvious entity, so to speak, such as a dog, we may also select a less obvious entity stuch as any organ, or any cell of any organ, of that dog; and may regard all else, i.c. the rest of the $\operatorname{dog}$ and all that is not that dog, as the environ- 
ment of the particular organ or cell under consideration. There can be no philosophic defence of any other course than this. We must be permitted to exercise our faculty of ideal isolation on any object or any portion of any object.

Now, when we come to concrete questions in biology, we find the importance of having clearly understood the use of the term environment. For instance, in the vulgar use of the term we speak of a dog (as an indivisible entity) and its environment; and we note that certain changes may occur in the dog's body as the result of its converse with the environment. But in the dog's body there are a number of germ-cells, which Weismann has taught us to consider as independent, as being not really part of the dog at all, but an immortal race of which the dog is the temporary trustee. Thereupon it is said that the environment may affect the dog but not its germ-cells. A corollary from the doctrine of the "continuity" and "immortality" of the germ-plasm is supposed to be the inviolability of the germ-plasm. But when we proceed to exercise the power already demanded and mentally isolate the germ-plasm of the dog, setting it up in antithesis to all else, we see that it is necessary to regard the body of the dog as the immediate environment of the dog's germ-plasm. The question then is: In what manner, if at all, is the germ-plasm of any individual organism affected by its inmediate environment-i.e. by the body of the individual?

For the present we are assuming the correctness of Weismann's contention as to the independence 
of the grerm-plasm. Our answer to the above question would be very different if we were to believe in, let us say, Darwin's theory of pangenesis. Darwin suggested that every cell and tissue of the body sent a representative contribution to the germ-cells, in which the individual was thus epitomised. Hence, to be consistent, if the individual lost a limb, the "gemmules" that should have been sent by it to the germ-cells were wanting, and that limb would be wanting in the offspring. But Darwin's theory is not held by any one; and we are at present compelled to consider the question from the WVeismannian standpoint.

Weismann himself once maintained the inviolability of the germ-plasm; but he has withdrawn that assertion. Here and there are to be found wholehearted Weismannians who declare that the germplasm is inviolable, but their position is, on the face of it, untenable. The germ-plasm is a living thing, and, like every other living thing, has an environment. It is self-evident that it must have relations with that environment. If the immediate environment-the body of the individual-dies, so certainly will the germ-plasm, a fact which is inclisputable and conclusive. What, then, are the precise relations of the germ-plasm and its host?

In the first place, the blood and lymph which are produced in the body, as a result of its converse with its (edible and breathable) enviromment, circulate through the germ-plasm. If the body takes in alcohol, which passes into the blood, the germ-plasm will necessarily be subjected to the influence of that drug. Further, if the budy be attacked by microbes 
and their soluble poisons or toxins enter the bloodstream, they will soon be brought into immediate relation with the germ-plasm. Again, the body contains many glands, such as the thyroid and suprarenals, which produce "internal secretions" that are carried by the blood to every part of the body and to the germ-plasm. Plainly, any doctrine of the inviolability of the germ-plasm is utterly untenable. Also-though this point is more intricate and debateable-the reproductive glands are subject to nervous influences. Nerves pass to them from the spinal cord, and no limit can be set, in the present state of our knowledge, to the nature or potency of the nerve-impulses that may thus connect the germplasm with any part of the body and, through it, with the remoter environment.

If, then, we accept Weismann's conception of the germ-plasm, we are now in a position tentatively to make certain $\dot{a}$ priori assertions as to the transmissibility of acquired characters-that transmissibility upon which Lamarck based his theory of organic evolution and of which Weismann denies the existence. We must beware of attaching too much weight to à priori reasoning, which has led men astray ever since they began to think; but nevertheless we are entitled to note the inferences which may be legitimately drawn from our premisses-whether or no these premisses be accurate. Later we must approach the matter from the side of observation and $\grave{a}$ posteriori reasoning.

But assuming the accuracy of our assumptions, we may say that we can readily conceive of the transmissibility of certain acquired characters. For in- 
stance, a man acquires immunity to a disease. That is to say, his body-cells, being attacked by microbes, undergo a change, whereby they constantly produce an "anti-toxin" which renders the further attacks of these microbes futile. The production of this antitoxin depends upon the previous production by the microbes of a toxin which circulates in the blood and lymph, and somehow causes the cells which it encounters to acquire the power of producing the antitoxin. Now the toxin, in such a case, nay be carried to the grerm-cells, and they, like the body-cells (which were originally derived from similar germ-cells) may undergo the changes which enable them to produce the anti-toxin whenever the appropriate stimulus is forthcoming. Plainly, in such a case, we can conceive it possible that the individual produced from one of these germ-cells should be immune to the disease in question. His father's acquired immunity will thus have been transmitted to him.

Sinilarly, other instances can be quoted where the modus operandi of the inheritance of an acquirement can be definitely conceived. Now we must remember that the Weismannian denial of the transmissibility of acquired characters was based not upon observation, but upon the doctrine of the continuity of the germ-plasm. On the 1)arwinian theory of pangenesis, the non-transmissibility of acquired characters was inconceivable. On the theory of the continuity of the germ-plasm, their transmissibility was alleged to be inconceivatile. When, however, cases are eited wherein the transmissibility - whether it occurs or not-is conceivable, as in the case quoted, the à priori argument falls to 
the ground; and since it no longer suffices to say that acquirements cannot be transmitted, we must resort to observation and experiment in order to find out whether they are transmitted.

But, on the other hand, there remains a great number of acquirements, the transmissibility of which is indeed inconceivable if we accept Weismann's theory of the germ-plasm. Many of these acquirements were once thought to be transmissible; many of them no one ever thought transmissible. Very few students ever thought the cerebral change which is implied in the acquirement of knowledge to be transmissible. The manner in which such a change could be reproduced in the germ-plasm through the agency of the blood, or the internal secretions, or the nerves, is inconceivable; whilst, in point of fact, we do not find that the child of a linguist is born with the "gift of tongues." But we may choose other instances, nicely graduated, so that it comes to be a matter of controversy, and almost of temperament, to say where the possibility of transmission begins or ends. Some of these must be noted; but, meanwhile, let me once more insist that we are now dealing with the conclusions as to the transmission of acquirements that may be drawn from the Weismannian assumption. We are not yet dealing with actual observation or experiment. Furthermore, it must be recognised that Weismann's theory of heredity is the most difficult to reconcile with the transmission of acquirements. If such a reconciliation can here be effected, much more easily can the transmission of acquirements be reconciled with any other theory, such as Hertwig's. ${ }^{1}$

1 See Chapter IX. 
We have already seen that it is inpossible to reconcile Weismann's theory of the continuity of the germ-plasm with the transmissibility of such local changes as ordinary injuries or mutilations. Neither the blood-stream nor the existence of "internal secretions," nor the nervous connections of the reproductive glands, helps us to conceive how a burn that destroys the skin of the father's back, let us say, can lead to the formation of a scar on the back of his child. ${ }^{1}$

But the fact that certain glands produco "intermal secretions" which pass into the blood and influence the rest of the body has been utilised as suggesting an hypothesis which may be of value. In every case where an organ or tissue produces a "specific secretion," that secretion may be conceived as having a specific action upon those "determinants" in the germplasm which are destined to give rise to the corresponding organ in a new individual. Dr. Vernon, who accepts this hypothesis, says: "It is almost inconceivable that each spot of skin on the borly, or each finger, should have a specific secretion, and that an injury to it, by changing its secretion, should so affect the germ-plasm as to produce a similar change in the corresponding area of skin of the finger of the offspring"; but he is prepared to adduce the hypothesis of specific secretions in a large number of cases, such as injury to, or feeble derelopment of. the brain, active exercise of the muscles, and so forth, where the belief in the existence of any specific secretion is entirely unsupported by nny recorded observations. In such cases it is as yot 
impossible to form any decision as to the applicability of this hypothesis.

Certain other transmissions of acquirements are compatible with Weismann's theory of the germplasm, but they may be mentioned only to be dismissed. The first of these, the influence of "maternal impressions," is of interest, because it serves to illustrate an important distinction.

We have already spent much space in observing the manner in which we may isolate, for purposes of thought, any entity, and then study its relations to all else. Now when the male and female nuclei have united to form the "segmentation-nucleus" so called since its segmentation will give rise to a new individual-there is plainly offered for consideration a distinct entity-the embryo. This also has its environment-the body of the mother. Nothing is truly innate or inborn in the embryo save what was present-as we say, "in embryo"-in the segmentation-nucleus. By an absurd and childish confusion of thought, we persist in attaching quite undeserved importance to the birth of any of the animals which are brought forth "alive." I Hence we speak of any character present at birth as congenital-which is etymologically justified; but we proceed to assume that congenital is synonymous with inherent or germinal. From our present point of view, it is an irrelevant detail that a young mammal happens to leave its mother at the ninth week or month. During the whole period that it spends within its mother, it is to be regarded as an individual organism, with its own environment. If that 
environment affects it in any way-stamps any character upon it, we speak nonsense if we declare such a character to be a transmitted acquirement. Pray let us observe clearly this distinction. If the mother's body, before conception, affects, in its rôle of environment, the female gamete, in such a fashion as to stamp upon it a character previously acquired by the mother, then this gamete, uniting with a male gamete and giving rise to a new individual, may certainly transmit to it a character acquired by the mother. Such a character is germinal or truly innate; for the coming into existence of any individual-its birth as a new individual - coincides with the conjugation of the gametes from which it is formed. 'The characters they confer upon it are inherited, in the proper sense, and a character acquired by the mother and reflected in her germcells, would thus be transmitted to her child. The mother's acquirement appears as a variation in her offspring. This case is fundamentally distinct from the impression of any character upon the embryonic but, nevertheless, distinct offspring during its development in the body of its mother. Such a character may be present at birth, but it is nevertheless not a variation but an acquirement. Plainly an acquirement is an acquirement whether it he acrquired five minutes or months before, or five minutes or months after, the change of environment which we call birth.

Hence it is evident that the alleged results of maternal impressions-as when a child is horn with a withered limb resembling one the sight of which had powerfully impressed the mother liefore her 
child's birth-would be, did they occur, in no proper sense instances of the transmission of acquirements. No more would it be a transmission of an acquirement for a mother to pierce her child's ear, her own having already been pierced.

Since we have quoted the belief in the influence of maternal impressions, we may briefly dispose of it here. The alleged instances are easily explained in any of half-a-dozen different ways. Given a deformity in her child, no self-respecting mother can fail to recall some accident of her pregnancy that immediately explains it. There is no reason to suppose that the few cases which read most strikingly are not explicable in accordance with the laws of chance. No obstetrician believes in the power of maternal impressions, and his knowledge of the relations of the embryo to its mother renders the exercise of such power utterly inconceivable to him. Finally, it is to be noted how ridiculous is the idea that such transmission of maternal impressions would have any bearing on the question of this chapter, even were it demonstrated to exist. In the asserted cases, the mother's acquirement is not a physical deformity, but an impression of one; the child, however, does not inherit that impression, but a deformity similar to that which impressed the mother. Really the whole theory is too silly for serious criticism; but it is of interest as throwing light upon the psychological processes of the innumerable mothers who believe in it.

Here, most conveniently, we may also deal with another fashion in which it is asserted that acquirements may be transmitted. The influence of 
maternal impressions and telegom? may conveniently be bracketed together in the rualer's mind as entirely supposititious phenomena which have been quoted in favour of the transmission of acquirements. "Telegony is the name given to the supposerl fact that offspring of a mother to one sire may inherit characters from a sire with which the mother had previously bred" (Chalmers Mitchell). For instance, it has been said that a mare which had born a foal to a quitgrga subsequently bore striped off'spring to a thoroughbred horse. But, as Archdall Reid points out, "If the white mother of a half-breed bear dark childrun to a white father, she would not transmit anything she acquired, for intercourse with a negro does not make her dark." In any case, it has been conclusively proved, mainly by the work of Cossal Ewart, that telegony does not occur.

Thus it appears that, though the transmission of certain acquirements is not incompatible with the theory of the continuity of the germ-plasm, yet the scope of such transmission inust be relatively small, if the theory be true. Darwin's theory of pangenesis. as we have seen, assumes the transmission of acquirements, but that theory is no longer held by any one, and its repudiation is a blow to the belief in the transmission of acquirements. Darwin himself believed in such transmission, but the neo-Darwinians or Weismannians repudiate it almost without reservation, and with it Darwin's theory of panerenesis. With Hertwig's theory of heredity the transmission of aequirements is quite compatible.

Lamarck's belief in the transmission of acquire- 
ments was based not on any theory of heredity, nor upon any experimental evidence. It was merely advanced as the most feasible explanation that offered itself of the fact of organic evolution. Since his day, however, the cases of apparent inheritance of acquirements have become explicable by the enunciation of the theory of natural selection, which the neo-Darwinians regard as practically the sole factor of organic evolution. Lamarck supposed, for example, that certain antelopes run swiftly because ancestral antelopes, in avoiding their enemies, developed the structures that subserve speed. Natural selection obviously furnishes an adequate explanation of the speed of the antelope we know, and so in innumerable cases. Hence we must look for positive experimental evidence of the inheritance of acquirements, such as cannot be explained by any application of the theory of natural selection. And when we come to inquire, it appears that such evidence is very hard to obtain. The effects neither of single nor of long-continued mutilations (i.e. mutilations often repeated in successive generations) are found to be inherited. The inheritance of acquirements due to use or disuse is unproved. The inheritance of the effects of changed conditions of life (i.e. changed environment) is dubious. Chalmers Mitchell regards it as uncertain; Reid as non-existent; Vernon as proved; Weismann himself as not proved, for he is able to adduce another explanation of the cases which appear to establish it. Then, again, we find no certainty, even after years of observation, as to the transmission of traumatic epilepsy, i.e. epilepsy due to the infliction 
of gross injury by external agencies. In short, the à posterior $i$ evidence tends, on the whole, to negrative the theory that acquirements are transmitted, but cannot be regarded as conclusive.

If, however, we consider certain facts of very lowly organisins, we do seem to find positive evidence. Haeckel, for instance, firmly believes in the inheritance of acquirements, and cites certain known facts of bacterial life. Disease-producing bacteria passed through the body of a susceptible animal are found to be increased in virulence. It is their favourable environment that confers upon several generations of bacteria their acquired exaltation of virulence, and they certainly transmit it to their descendants. Here, indeed, appears to be a conclusive instance of the transmission of an acquirement.

Thus we are compelled to leave this controversy unsettled. We may tentatively incline, however, to the following conclusions:-

The transmission of certain aequirements is not incompatible with Weismann's theory of heredity, and is perfectly compatible with Hertwig's theory, which is far from being disproved.

Certain instances of transmission of acquirements appear to be known.

The transmission of acquirements is far more limited, assuming it to occur at all, than used to be thought.

However fully it were admitted, it could not explain all the facts of oratuic evolution.

Numberless supposed instances of the transmission of acquirements can be more easily and satisfactorily explained by means of the theory of natural selection. 
The dogmatists should avoid this controversy in its present stages. It will not satisfy their love of positive assertions, and their tendency to make such assertions does not serve to its solution. ${ }^{1}$

\section{CHAPTER XI}

THE RELATIVE IMPORTANCE OF HEREDITY

\section{AND ENVIRONMENT}

According to science, all living things are determined by two factors, heredity and environment, and by those alone. 'This dogma applies to all vital and psychic activities, the human will most certainly included. ${ }^{2}$ But ere we come to look into it more closely, let us obviate a frequent misconception. Shakespeare's parents were unremarkable, and he had six quite commonplace brothers. Plainly, then, he did not inherit his genius; and no one will maintain that it was produced by his environment,- - poeta nascitur, non fit. What, then, becomes of the assertion that every living thing, in all its activities, is conditioned and determined by heredity and environment?

The objection depends upon a most excusable misconception. Certainly Shakespeare's parents could not have written "Hamlet," even in collaboration; certainly his environment did not generate "Hamlet" within him. His genius was innate, inborn; the poet

1 The relations of psychology to this controversy are discussed in the chapter, "The Origin of our Ideas," in the author's companion volume on "Psychology."

2 See "Psychology," "The Human Will." 
is born, not made. Plainly, then, he did inherit his genius; not in the sense that his parents had it, but in the sense that it was potential in those two cells -or in one of them, or in their combination-which were derived from his parents and went to form him. It may be objected that one cannot inherit that which one's parents have not grot; but obviously our quarrel is merely a matter of terminology. Let us reconsider it.

It is immediately evident that Shakespeare's genius, like any other character peculiar to him, such as the lines of his mouth, or the particular ratios of his finger-lengths, was a variation. Now, according to the old manner of thinking, this is as much as to say that it was not inherited, variation being the "opposite" of heredity. But we have already seen that this view is untenable; that variation is really a form of heredity. Surely this must be apparent, if we look at the concrete case in point. It may be said that Shakespeare could not inherit what his parents had not; but it cannot be gainsaid that, in point of fact, the particular variation which we call his genius was innate-according to the Latin tagor, in the language of science, was germinal. It was potential in the cell from which Shakespeare was formed; and that cell, with its potentialities, was formed from parts of two cells, one contributed by his father, and one by his mother. If, then, ho did not get his genius from his parents, it was at any rate potential in that which he indisputably grot from his parents and from which he was formed. In this sense, variation is a form of heredity.

Let us now attack the familiar debating-socicty question as to the relative importance of heredity 
and environment: understanding that the word heredity is here used in its widest sense, as indicating the whole of that process by which a man's ancestry affects him. Our answer to the question is at once seen to be clear and decisive. Certainly the poet is born and not made; but so is the pig. The pig is a pig because it was born a pig, not because its environment made it so. Similarly a man is not a horse though he may have been born in a stable. Everything that constitutes a pig a pig, a man a man, a genius a genius, is really inborn; that is to say, is a matter of heredity or ancestry. Even if such a variation as genius seems to be plainly not a matter of heredity in the limited sense, it is a matter of ancestry; infinitely more a matter of ancestry than of environment. A Shakespeare could not be born to a sow or even to a Fuegian woman, no matter what environment was provided. "Race is everything," said Disraeli.

That, of course, is an exaggeration; and it is therefore necessary that we should attempt to estimate the power of environment. Firstly, then, environment is impotent to create : the poet is not "made," nor the pig. Charm it never so wisely, the environment can only affect the development of the potentialities already present. Every man thinks he could play billiards as well as John Roberts if only he had time to practise enough; but he is wrong. His innate characters-and therefore his ancestry-are already determined, and infinite practice will not make him another Roberts unless he was born one. Practice can make perfect only "what's bred in the bone." 
Plainly this is a fact of very great practical importance. Just as the discussion as to the inheritance of acquirements directly deals with the utility of education to the future race, so the fact that the environment can only determine the scope of innate characters and can never create even the smallest character, affects profoundly our estimate of the importance of education to the individual. What we commonly understand by education is simply a particular portion of the environment. In my opinion, the only adequate and scientitic definition of uluention is the provision of an environment. Thus, using the word in its largest sense, we see that all experience-which is converse with the environmunt-is educative. But, further, our study of the relation between environment and heredity prepares us to appreciate the fitness of the word education. I have defined education as the provision of an environment. and we have already seen that the enviromment never creates but merely acts on the materials provicled by heredity. Note, then, how tit the word education is; it signifies a leading forth. This is precisely what the environment does; it leads forth the characters already present in the individual. We must emphatically realise that elucation-i.e. the action of environment-is thus incapable of creating a poet or a billiard-player or aught else; but, if the organism has these potentialities, education will give them seope.

However, we must not omit the consideration of the negative action of the environment-and therefore of education. The word is not perfect, fur it ignores half the business of education, which is not merely a leading forth but also a joroing back. 
Seduced by the current notion that education is a matter of imparting knowledge, we are apt completely to forget this aspect of education, its action in repressing certain potentialities of the germ so that they never realise themselves. Yet it is at least as important a function of education to "let the ape and tiger die," as it is to educe the higher potentialities. This we shall better understand if we accept the proposed definition that education is the provision of an environment.

For observe that though the environment can never originate-that being left to heredity or ancestry alone-it can totally suppress any germinal character, so that it might never have been. The infant Shakespeare, transported to Tierra del Fuego, had never written a "Hamlet." When this consideration is well turned over in the mind, we see that the action of the environment-i.e. education-is not to be regarded lightly, merely because we have insisted upon the prime importance of heredity, and the impotence of the environment to do more than work upon the material offered it. We must remember that the inherited potentialities of the germ are only potentialities; no more. They are entirely at the mercy of environment. If that be completely unfavourable, the organism, with all its innate characters, will die. If the environment be favourable enough to permit of life, it may yet effectively arrest the expression of any potentiality given by ancestry. We have already noted that this power of the environment may be utilised-for the ancestry includes the "ape" if not directly the "tiger" of Tennyson's line. On the other hand, we have to note that this 
repressive action of the enviromment may be most pernicious. Most precious potentialities given by ancestry may as well not have been given at all, so completely does the environment prevent their realisation. The illustration of the infant Shatespeare amongst savages is extreme; but every one can ponder on this point for himself. I will merely allude to the many cases where some chance circumstance-i.e. some fact of the environment-has disclosed powers of mind or body which were previously totally unknown to their possessor-if he can be called their possessor so long as the enviromment prevented him from entering into his inheritance.

Observe, then, the admirable perfection of Hurbert Spencer's aphorism, "To prepare us for complete living is the function that education has to discharge." The edueation, or environment, provided which fails to lead forth or which actively suppresses any desirable potentiality of the germ is inadequate; for the function of education is to make possible complete living-that is to say, the realisation of every desirable potentiality which ancestry has implanted in the germ.

For instance, ancestry-by which I mean the whole past of the race-may have implanted in the germ a potentiality for the making of music. But this potential character may be a variution: the child's father is not musical. The father, unfortunately, who has not read the story of the littlo Handel, knows nothing about spencer's "complete living," nothing about the duty of so forming the envirunment as to provide for the education or leading forth of every desirable character of tho germ, whether it 
be a variation or not. And so the boy has to tight for the education, or environment, which the musical potentiality in him demands for its education. A father can never tell what variation may bring forth, and it is therefore his duty, since he remembers that an unfavourable environment (e.g. the wrong sort of education) may suppress or atrophy a precious variation, closely to study his child, so as to discover what its germinal-innate, inherited-characters are. Thereupon he will so construct the environment of his child (i.e. will so educate it) as to suppress the bad potentialities and educe the good. Nor will he, if he be a student of heredity, too readily assume that potentialities unexpressed in himself may not be present in his child. Such potentialities may have been innate in the father but suppressed by his environment; or their occurrence in the child may be a true variation, i.e. a character innate in the child but unpossessed by the parent.

This is one of the cases where we require to take Dr. Johnson's advice and "clear our minds of cant." The cardinal primacy of heredity as compared with environment, a primacy on which I have surely insisted in the preceding pages, and the marvellous fashion in which genius can triumph over the environmentremould it to its heart's desire-and notably our very natural preference for the belief that "genius will out," have led many to maintain that Gray was wrong when he wrote the familiar lines:-

"Perhaps in this neglected spot is laid

Some heart once pregnant with celestial fire,

Hands, that the rod of empire might have sway'd,

Or wak'd to extasy the living lyre. 
But knowlerlge to their eyes her ample prage

Rich with the spoils of time dirl ne'er enroll;

Chill penury repress'd their noble rage,

And froze the genial current of the soul."

We are told that there are no mute inglorious Milcons and that in point of fact genius always commmands and creates its own enviromment. No fragment of proof is ever offered in support of these assertions, save the argument-which would not impose upon a childthat many instances of the triumph of genius over obstacles are recorded in biographical history. It behoves us to understand that, though environment cannot create, it has the last word, and that unly by the happily adjusted interplay of heredity and environment can any organism attain to "complete living." Life is the "continuous arljustnunt of inner" to outer relations."

Hitherto we have discussed only the relative importance of heredity and environment to the individual; but what of their relative inportance to the race? Plainly, if acquired characters are not transmissible, or, to state it more comprehensively; if the action of the environment upon the individual never reaches the germ-plasm, then the importance of environment to the race is nil, so far as positive action is concerned, but great in so far as it deerees which individual shall propagate his like and which shall not. If, however, the action of the environment cannot be denied access even to the germ-plasm, then its potencies are to be regarded as immeasmrable : and it becomes a duty of mankind to exercise its power. its unprecedented power, of so modifying the environment that the grerm-plasm of any generation may be educated for the veuctit of the next. 


\section{CHAPTER XII}

\section{HEREDITY AND “PHYSICAL DEGENERATION"}

OF late we have heard much of the "state of the national physique" and "physical degeneration" or "degeneracy." Royal Commissions have been hinted at, and, in the course of time, some bright statesman may even contemplate the advisability of doing something to counteract a grave and increasing evil.

But it first behoves us clearly to understand what the evil really is. The term "progressive degeneration" has been largely used in the recent discussion of this subject, and plainly contains a reference to heredity as a factor in the problem. Even wise and serious students have inclined to the popular view. Dr. William Hall, of Leeds, for instance, who has long worked at the subject, was at one time inclined to believe that heredity, as shown in the difference between the Jewish and Gentile children whom he examined, might be an important factor in the production of this so-called "physical degeneration." But Dr. Hall has now entirely altered this opinion, and his change of view may be regarded as extremely significant. Dr. Hall found that the infinitely superior feeding and environment and parental care in general of the Jewish children abundantly accounted for their great physical superiority to their Gentile playmates.

Now if it can be demonstrated that " physical degeneration" is a misnomer as applied to the poor 
children of our cities, and that heredity is not a factor in the production of their wretched physique, but that their environment is all-important and alleffective, the demonstration is to be welcomed and recognised by those who are striving to end a state of things which is amongst the many scandals of our civilisation.

It appears to me that, both on à priori and d̀ posteriori grounds, we may exclude the action of heredity in this matter.

The à posteriori grounds for ignoring heredity are as follows. In the first place, none of the actual evidence adduced is in any way in favour of the view that this is a progressive change-i.e. a change progressively increasing from one generation to another. Dr. Leslie Mackenzie, of Edinburgh, is one of the tirst living authorities on this matter. He says that by racial degeneration he understands the transmission of weakness and disease from one generation to another, whereas the results of his inquiries have been to show that, in the overwhelming majority of cases, there was nothing which would have prevented the children from growing up healthy and fit had they been reared in a better environment.

The à priori argument agrainst the reference of this "physical degeneration" to the action of heredity is even more important. The majority of those who have asserted the occurrence of a progressive change appear completely to ignore the fundamental principles of the evolutionary biology. They make no allusion to the fact that their assertions run directly counter to the law of natural selection. Thoso who assert that there is a progressive degeneration occur- 
ring amongst any classes of our people have it incumbent upon them to demonstrate either the falsity or the suspension of the law of natural selection. Biology asserts that hereditary degeneracy is necessarily doomed to extinction, provided that there obtain the conditions that make for any selection at all. As long as there is a struggle for existence the fittest must survive. This à priori argument against the existence of a progressive degeneration amongst our people is not properly complete unless the objection be met that the "fittest"-as I seek to show in the volume on organic evolution-does not necessarily mean what we call the "best." The fittest are merely the most perfectly adapted to the conditions of the environment. No one, however, will maintain that, even in the highly "unnatural" environment of civilisation, or even the malignant environment of crowded cities, the physically "degenerate" are any "fitter" than their neighbours. Indeed, they are obviously less so: they tend to an early death, to a relative or absolute sterility, and their stock soon dies out.

Later we must meet the argument of the Cessation of Selection, which declares that heredity is a factor in this question, because the law of natural selection has been abrogated by civilisation, and thus the deteriorates are allowed to propagate their deterioration.

Meanwhile, however, let us notice the consequences that must follow upon the exclusion of heredity from this problem, and the reference of the facts to the action of the environment alone. This advance in the discussion not only greatly simplifies 
the subject, but it also is exceedingly comforting. Were we compelled to helieve that a representative section of the Aryan race, such as ourselves, is undergoing an hereditary, racial degeneration, either owing to some maleficence of the environment which made the fittest of Spencer's formula the worst according to our ordinary standards, or owing to the abrogation of the law of the survival of the fittest, or owing to a racial senility, then the conclusion would be that the white race as a whole is probably donmed to extinction-perhaps hastened by the incursion of the Mongol. There would thus be raised issues of planetary significance. If however; the action of heredity be excluded, we have to face a very much smaller and very much more hopeful problem; this, namely, that certain conditions of the environment. such as city life, bad feeding, alcohol, foul air, and su forth, are causing a certain number of individuals in each generation to undergo a physical deterioration in the course of the individual lifetime. Of these a certain number may possibly add hereditary degenerates to the next generation, but the law of natural selection-if it be still in action-ensures that their race soon dies out.

Let us then revise our terminology. The word degeneration-a coming "down from the genus" is certainly applicable to a progressive endition in which each generation produces, in virtue of heredity, another worse than itself. 'This is just the condition which, as I believe, does not hold in the case under discussion. The term deterionution, on the other hand, meaning simply "a becoming worse," is more fitted to the case as I believe it to be. A racial 
degradation may well be called degeneration; an individual degradation, due to the malign influence of the environment upon an organism which is not inherently or germinally degenerate, is best termed deterioration. In order to avoid the obvious implications of the term degeneration, its use should be abandoned by writers on this subject; unless, indeed, they believe that the condition is an inherited progressive degeneration.

Increasing this evil doubtless is, for the conditions of city life are daily becoming the conditions of more and more of our population. The denial of the occurrence of a hereditary degeneration by no means implies that the number of persons physically deteriorated in this country is not increasing. The contention may be hazarded that the increase in the number of those who thus deteriorate is proportionate to the increase in the urban as compared with the rural population.

There are falsely assigned at least three proofs of physical degeneration. These are-(1) the increase in insanity, which implies an increase of morbid physical states; (2) the steady fall in the birth-rate; (3) the undiminished-though not markedly increasing-infantile mortality.

Of the increase of insanity there is no proof, and it need not further detain us.

The fall in the birth-rate cannot possibly be regarded as proof of a progressive (i.e. inherited) racial degeneration, since its causes are well known and are totally irrelevant. The still scandalous rate of infantile mortality is alleged as a proof of racial degeneracy, it being supposed-by persons of extra- 
ordinary ignorance-that the infants die because they are too degenerate to live. On the other hand, we know that a child which has survived the vicissitudes of intra-uterine life, and the dangrerous episode of birth, has already given proofs of vitality, and that in almost every case there is no inherent (i.e. inherited) reason why it should die. We know. furthermore, from the comparative death-rates of breast-fed and non-breast-fed children, and from all the other relevant considerations, that extraneous circumstances (i.e. the conditions of the environment) determine the overwhelming majority of these deaths. The infantile mortality is not a proof of failing national physique, but of the miserable inefficiency of the national conscience. The infantile mortality, and the wretched physique of certain classes of the people, are both consequences of the same causes, viz. the aboininable environnent which we provide for only too many of the nation's children.

Let us now consider three causes which, as I believe, have been falsely assigned in explanation of physical deterioration, each of these causes involving an assertion in heredity.

The first of these assertions is that the continuous increase of the average age of marriage is partly responsible for the facts. In this country the average age of men at marriage is now very nearly $28 \frac{1}{2}$ years, as compared with 28 years a generation agro. During the same period the average ane of women at marriage has increased from about 25 years and 8 months to 26 years and 3 months. But, even apart from the fact that the change is so 
small, there is no evidence, or even likelihood, that the gametes of a man or woman of, say, thirty-five are in any way inferior to those produced ten years earlier. If increasing years did indeed affect the germ-plasm, either adversely or favourably, or in the direction of greater or less variation, or, indeed, in any fashion at all, the fact would obviously be of immense importance to the student of heredity. But if we confine ourselves to the normal reproductive period, there is no reason to believe that there is any such relation between the age of the individual and the nature of the germ-plasm. So far as his knowledge of heredity can guide him, the observer need have no cause to regret the present increase in the average age at marriage - an increase which may otherwise be welcomed for many reasons. But it is well to recognise that there may be facts of importance with which we are yet unacquainted as to the influence of the age of the individual upon the germplasm. So far we are able to make any definite assertion only as to the relation between size of family (which is obviously correlated with the age of the parents) and mental characters. Thus Harelock Ellis ${ }^{1}$ finds that genius is one of the abnormalities associated with families of large size. This holds good whatever century be taken for study. Galton ("English Men of Science") obtained a like result, as have other students. Toulouse, Magri, Langdon Down and Cassel are quoted by Havelock Ellis as having shown that insanity, imbecility, hysteria, and neurasthenia are more frequent in large than small families. It would obviously be premature to attempt 1 "A Study of British Genius," 1904, pp. 106 et seq. 
any interpretation of these facts. It suffices that the available evidence by no means supports the view that the present state of the lower classes of our urban populations may bo ascribed, even in part, to the increase in the average age of the parents of this people.

The second cause assigned without proof as explanatory of the imperfect physique of many is the alleged "multiplication of the unfit"-the produrtion of degenerates by degenerates. To this allusion has already been made. It assumes, first, the ability of the degenerate to propagate. Now it is impossible to maintain that no degenerate-we assume that this word answers to a fact and not a fiction-is capable of reproduction; but it is worth remembering that a relative or absolute sterility is a distinguishing mark of degeneracy. The assertion of the "multiplication of the unfit" assumes, secondly, the cessation of selection, or its partial supersession by the social conditions of our time. This matter will shortly be dealt with.

The third falsely assigned explanation of the unsatisfactory state of the national physique is that based upon the assumption of a general, inherent, inevitable, national-racial decadence-the multiplication of adjectives being in inverse proportion to that of evidence in support of this contention. It is asserted that the Anglo-Saxon race has reached its zenith and is now in process of decline. ${ }^{1}$ The

1 It has already been noted that Dr. Hall, of I,eecls, was formerly inclined to postulate some racial law of rise and fall in explanstion of the differences which he olserved between Jew and Gentile children in that eity. But now he attributes these differences to the fact that "the Jews know how to feed their children properly." 
physical deterioration witnessed in our great towns and cities is cited as $\grave{a}$ posteriori proof of this racial senility, and, though no explanation of the details of the process is advanced, $\grave{\alpha}$ priori arguments are also forthcoming. In the first place, there is the argument from analogy. As the individual grows and reaches maturity, and declines and dies, so plainly must the race. This type of argument appeals to many minds, but it is worse than worthless. It needs no expert logician to detect the palpable fallacy involved. Because the race may be likened to a living entity, such as the individual, whatever is true of the individual is true of the race! On the contrary, the individual and the race are far more truly antithetic than analogous. The profound contrast between them is that the individual is mortal, the race immortal. Being mortal, the individual must die-that is evident; being immortal, the race does not die. Hence the suggested analogy is worthless.

Another argument is based upon what is commonly called history. Other races have risen and fallen, and so must this. Here, again, is one of the many accepted beliefs which are accepted simply because they are not analysed. No known factor or fact of organic evolution or heredity helps us in the smallest degree to understand how or why such an inevitable decadence should occur. It is quite incomprehensible that the physical factors of the germ that make for success should contain within themselves a principle of decay. When we come to look at the facts of history more closely, we discover abundant evidence to show that the phenomena of the rise and fall of nations are not dependent upon physical or organic 
factors, but upon psychical, sociological, super-organic factors. The decline of nations is not a theme for the biologist, the student of heredity, but for the sociologist and the moralist. But it is highly necessary for the student of heredity to affirm, and again and again to affirm, that he knows no cause whatever why nations should decay. His study throws no light on the phenomenon, or, rather, it does throw a light upon it by demonstrating that there are no facts or factors of heredity that explain it. Hence when the moralist seeks to explain the causes of national decay he is justified in his preaching by the positive assertion of the biologist that there are no physical facts which explain such decadence, and should the historian seek to save himself the trouble of finding the true explanation, and hint that the decay of nations is due to some obscure laws of heredity as yet uneluciclated, his listeners must be warned that the student of heredity will countenance no such explanation. In the organic world success makes for more success; it is not to the facts of the germ-plasm, but to the facts of mind and morals, that we must attribute the decline and fall of any empire or nation. 'Thus a nation may be tottering to its fall, whilst its stalwart sons-" superb specimens of physical manhood"-are breaking all athletic records.

One important point remaius to be consideredthe alleged cessation of selection. If selection has ceased, then the it priori objection to the belief in a progressive physical degeneration is disposed of. If there is no selection, plainly, the untic 
are free to multiply, if their unfitness does not interfere with their reproductive powers; and the further question will then be raised as to how far their unfitness, whether acquired or germinal, is transmissible.

But if the biometricians have conclusively proved anything, it is that selection has not ceased among civilised peoples. As Professor Pearson has said, no one can look at a mortality-table and believe that selection no longer occurs; and as Reid says: "If natural selection no longer eliminates the unfit among civilised peoples, it is evident that most people must die of old age, or else that the elimination is not selective. But, as a fact, millions of people perish, even in England, which is highly civilised, before or during the child-bearing age, nearly all of whom are eliminated because they are constitutionally incapable of surviving under the ordinary conditions of the environment in which they find themselves."

The vast majority of human deaths, especially among civilised peoples, are due to disease; and disease is unquestionably selective. Thus, though we may freely admit that the general tendency of many charities, of many laws, and the work of the medical profession is directed against the operation of natural selection, yet this factor of evolution is very far from having ceased, even amongst the most civilised peoples. It cannot be argued that the physical deterioration witnessed in our cities is the result of the cessation of natural selection.

On the other hand, we must not flatter ourselves that no action on our part is required; that the 
selective process is doing all that any selectivo process can do. On the contrary, we must recognise that certain modern doctrines and practices do tend ${ }^{1}$ towards the most unwise and disastrous limitation of the action of natural selection. It is not well that civilisation should interfere with natural selection, and artificially facilitate the reproduction of those aftlicted with certain forms of vice or mental or physical disease. Furthermore, it is our duty: having recognised the potency of heredity, and therefore the importance of the principle of seluction to aid its action, and extend it in accordance with our ideals. ${ }^{2}$ If artificial selection is worth while in the case of race-horses, it is worth while in the case of man.

\section{CHAP'TER XIII}

\section{HEREDITY ANI) DINEASE}

THE title of this chapter covers several suljects which are not closely related to one another, but which may be conveniently dealt with under this heading. The first of these is of little importance in connection with the theory of heredity. but others are of high theoretical interest.

The inheritance of disease is a subject on which our opinions have lately undergone a profound revolution. 'This is indeed to be expected, if we remember that it is but a few decalles since wo

1 See the chapter, "Socialisn,," in the volume "sociolury."

2 See the chapter. "The Future Evolution of Man," in the wolune "Organic Evolution." 
gained any considerable knowledge of the causation and essential nature of the vast majority of all diseased conditions. The study of the inheritance of disease entered on its first fruitful stage when Pasteur and his followers taught us that nearly all disease is due to the invasion of the body by microbes or bacteria. As it is daily becoming more difficult to name any important diseases-save probably cancer-that are not of microbic origin, we shall here take for granted a practical identity between "disease" and "disease of bacterial causation."

Plainly the greater part of our discussion will have little bearing at this stage on the general problems of heredity, but will be concerned rather with the habits of various bacteria, and the possibility of their communication to the germ or the embryo. Let us take, for instance, the most important of all diseases, which probably slays about one in five, six, or seven of all the human beings that die upon the earth. We now know that "consumption" and a hundred other diseased conditions are due to the invasion of some part of the body by a minute plant called the tubercle bacillus or bacillus tuberculosis. It is still widely believed that tuberculosis is hereditary.

But to the modern pathologist this statement can only mean that the tubercle bacillus may invade the germ-cells by direct passage from an infected parent; or may enter the embryo from the body of an infected mother. Thus the child at birth will contain tubercle bacilli. This the pathologist would term congenital or hereditary tuberculosis. Plainly, however, it would be desirable to use these terms 
more accurately. The entrance of bacilli from the body of the mother into the body of an unborn child is not to be distinguished from the point of view of the student of heredity, from the infection of the child, after birth, by bacilli derived from the mother; nor is this to be distinguished from the spread of infection from the mother to any other child or adult. It is, doubtless, of great pathological and practical interest and importance to discuss the possibilities of the infection of the embryo, or fotus, by the mother, but the presence of tubercle bacilli in the child at birth, as a result of such infection, should properly be called congenital not hereditary tuberculosis. One organism living within another which is the host of a parasite, such as the tubercle bacillus, may well be specially liable to infection; but that fact is of little interest to the student of heredity, which is the tendency of like to beget like.

The point must be insisted upon, for current medical and popular nomenclature takes no cougnisance of what is really a cardinal distinction. The ante-natal infection of an emliryo, or foetus, is a special problem in the general subject of infection. Strictly speaking, it has nothing whatever to do with the subject of heredity. Another instance, by no means uneommon, is worthy of eitation. The disease known as acute rheumatism, or rhenmatic fever, is due to a particular microbe called the diplocorcus rheumaticus. This microbe not infrequently attacks a pregnant woman. During the course of her attack of rhenmatic fever, the poisons produced by the diplococcus circulato through her blood, and only too often attack the valves of her 
heart, especially those of the left side of the heart, which is subjected to greater strain. But these poisons, or toxins (the plural is used not because there is definite evidence that there are more than one, but because we know little of their nature as yet, the diplococcus having only very recently been (discovered), are also contained in the blood which the mother sends to the placenta; and that organ is apparently unable to prevent their passage from the maternal to the fotal circulation. Hence the toxins may attack the heart of the child, especially the valves of the right side, which are subjected to the greater strain in intra-uterine life. The child is thus born with "congenital heart-disease," or, to use the doctor's slang, " a congenital heart." Now, observe the broad results as they would appear, say, thirty years ago, when the bacterial origin of rheumatic fever was not even suspected. The mother has the rheumatic "diathesis," or "constitution," or "dyscrasia" - the greater the ignorance the more luxuriant the terminology - which results in heart-disease. The child is born with heart-disease absolutely identical save for a slight difference in its site. Plainly the child has inherited the maternal "diathesis."

But now we know the actual facts of the case, and we perceive that they really have nothing to do with the problems of heredity proper. The baby's heartdisease is not due to its having inherited the "rheumatic diathesis" from its mother, but to the circumstance that during its life within the mother certain poisons circulating in the mother's blood happened to pass into its blood and, as is quite intelligible, caused injuries within its body similar to those pro- 
duced within the body of the mother. Profoundly interesting and important all this doubtless is ; and so are a hundred other cases more or less parallel with it, such as the killing of the child by the giving of poison to its mother, or the possible treatment of the suckling child, after birth, by giving castor oil to its mother. But these are not cases of heredity, save in so far as the child's tissues inherit those characters of the maternal tissues which make them respond in certain fashion to the action of the rheumatic toxin, or mercury, or castor-oil. 'This we now see clearly, but it is well to remember the totally different aspect which the facts necessarily wore when the nature of rheumatic fever was unknown. Meanwhile there remain not a few diseases, such as gout, of which the causation is still unexplained and about the inheritance of which it will be well to preserve some reticence until haply we may "know what we are talking about."

But before we leave this part of our subject we may note one or two very interesting facts which, as we are now able to recognise, are not facts of heredity. though they may appear to be such at first sight. We have already observed how the passage of poisons from the blood of a mother to the bloorl of the unborn child may give rise to the appearance of inherited disease. Similarly a child may acquiro immunity from various diseases or poisons, but this immunity is acquired - not inherited, or innate, or "natural." For instance, Ehrlich, the greatest living authority on immunity, has shown that the oftspring of mice who had acquired an immunity to the action of certain poisons, were themselves immune, if both parents or the mother alone had been immunised; 
but were susceptible if the father alone had been immunised. He further proved that this so-called inheritance of immunity is not a true inheritancewere it so, it would clearly be a case of the transmission of an acquired character-but is an acquirement of the young mouse, partly due to the passage before birth, of certain substances into its blood from the blood of the mother and partly due to a subsequent transference of these substances by means of suckling. Plainly it is all one to the student of heredity whether the young mouse acquired its immunity from the blood with which the mother fed it before birth or from the milk with which she fed it after birth. The case is not one of heredity. Similarly the human infant may acquire immunity through its mother's milk. Ehrlich is inclined to think that the very general immunity of the human infant from a number of infectious diseases, such as mumps, scarlet fever, and measles, during the first year of life, is due to its constant imbibition in its mother's milk of protective substances poured into the mother's blood by her body-cells in consequence of their acquired immunity to the diseases in question. Plainly this also is no case of heredity; for the sequence of events could be paralleled by the precipitation of these protective substances from the milk of any immunised animal, and their administration to the child. Problems of heredity will arise when we ask ourselves whether the immunity acquired by a mother or a father can so affect the germ-plasm as to endow the offspring with a truly inherited immunity. We have already seen that in the case of the paternal mouse, immunised against certain 
poisons, the germ-cells were unable to transmit such immunity. Apparently they were unaffected, even by the presence of these poisons in the blood that passed through the reproductive glands.

Let us now revert to the typical question of the inheritance of tuberculosis, and inquire as to the occurrence of anything that may properly bo termed a fact of heredity.

It is conceivable, as we have already observed, that the inale or female gametes of any tuberculous parent might be infected with tubercle bacilli, and the changes they wrought in such gametes would doubtless affect the "segmentation nucleus" (the nucleus of the first cell of the new organism); but even this state of affiurs is scarcely cognate to the problem of heredity proper, though it must later be considered.

In point of fact, however, so-called hereditary or congenital tuberculosis is practically non-existent; one or two cases have been recorded, but they are merely pathological curiosities. The germ-cells of tuberculous parents are not-save perhaps once in millions of cases-infected by the tubercle bacillus. Furthermore, it has been discovered that the placenta, or after-birth, the organ of communication between the mammalian mother and her unborn child, possesses the power of filtering the blood ${ }^{1}$ which passes through it, so that bacteria which may be present in the maternal blood do not, save in a quite infinitesimal proportion of cases, gain entrance to the body of the child. 'Thus it may be

1 This is lonsely expressed, but with suflicient accuracy for the present purpose. 
fairly stated - the exceptions being negligible-that the new-born baby is "aseptic," "sterile," or "germfree," even though one or both of its parents may be subjects of microbic disease. This assertion is tantamount to a denial that the inheritance of disease is a fact of any importance or frequency.

But now we must proceed to make a most important qualification of this very important statement-a qualification which enables us to answer the very just criticism that, despite our theories, germ-diseases are daily seen with most suggestive frequency in parents and their children. It is true that this criticism is largely irrelevant; for the explanation of the occurrence of the same disease in parents and children often is that the children have become infected by their parents. A recent writer even inclines to the view that the apparent inheritance of some factor-immediately to be considered -in tuberculosis is largely to be accounted for by the fact that the children of tuberculous parents are so gravely exposed to infection. Nevertheless, there doubtless is a factor in tuberculosis, and the many diseases of which we have taken it as the type, which is inherited-the factor of susceptibility.

In all microbic diseases there are two cardinal factors: the presence of the causative parasite, and the receptivity of the host. Or, if we figure the disease as a crop or harvest, we may say that it depends upon the mutual fitness of the seed and the soil. This becomes apparent directly we accept the germ theory of disease. A cat may suffer from diphtheria, and so may a baby: either may infect the other. But no cat ever caught scarlet fever from 
a baby. Similarly the mierobes of certain diseases demand for their soil the tissues of man or of a higher ape, the lower ape, the lemur, and all other animals being insusceptible or immune. Again, there is one kind of sheep which is immune to a disease that readily attacks all other sheep; and so on, without limit. Plainly there is a question of hererlity here.

When we attempt to name the factors of suseeptibility or of immunity we find ourselves in diflieulties. For immunity or heightened susceptibility may be acquired by the individual as a result of actual experience of the disease. Immunity or susceptibility may vary in its degree from day to day, or from decade to decade. It may be relative or absolute, temporary or permanent, natural or acquired. But in every case true immunity or susceptibility must ultimately depend upon the facts of cell-chemistry, and in many cases these facts must be of very ancient origin. The natural susceptibility of the chimpanzee and of man to a certain disease plainly depends upon inborn characters which have been transinitted throngh thousands of generations. Their immunity to the tsetse fly disease of the horse is similarly a fact of heredity.

But we have already seen that immunity or susceptibility may be confined to certain varieties within a species, as in the case of the sheep. Similarly it appears that different races of men, and even different families of the same race, vary widely in these respects. And the most important fact is that these characters of natural immunity or susceptibility to one disease or another are tramsmissible by heredity. This fact serves to solve our practical prohlems. 
For instance, medical men now believe, as we have seen, that consumption is not hereditary, but, on the other hand, that the "tendency" to consumption, or the consumptive "diathesis," or the higher degree of susceptibility to the attacks of the tubercle bacillus, is hereditary. On every ground the distinction is well worth making. In the first place, it now appears that there is no inevitable curse pronounced upon the child of the consumptive. $\mathrm{He}$ probably inherits from his parent that special degree of susceptibility which proved fatal to that parent. But he has not inherited the disease itself. And let us recall the chapter on the relative importance of heredity and environment. The exceptional susceptibility to tuberculosis is only a potentiality, and the environment has the power of developing, or suppressing, or modifying it. Thus the child of the consumptive may live in such an environment-I am tempted to say that environment in this place practically means open bedroom windows-as to suppress this potential susceptibility, and he may indeed, though he has inherited this malign potentiality, acquire a high degree of immunity. I speak of the specific case, not of all microbic diseases. But it is evident that the practical problem for the child of the consumptive is not patiently to await an inevitable doom, but to overcome heredity by environment-in his case notably the atmospheric environment.

In the second place, the distinction between the inheritance of a disease and the inheritance of a susceptibility to the attacks of an external cause of disease is worth making, because of its bearing 
upon social as well as individual practice. If it could be demonstrated, for instance, that the susceptibility to certain grave diseases is confined to certain members of the community, who inevitably transmit it to their children, we might well regard it as a duty to interfere with the reproduction of those persons-as would the disease itself, in accordance with the law of natural selection.

In the third place, it is of importance to consider whether susceptibility to a disease acquired by an individual can be transmitted to his off'spring as an actual part of the germinal inheritance. But, in brief, it may be said that the study of heritability of disease does not reveal any exceptions to the laws of heredity observed in normal cases.

Having excluded so many familiar cases as not properly to be called facts of inheritance, let us now consider the true cases of the inheritance of disease.

And, first of all, let us note the existence of certain nervous abnormalities which are inherited. Merely mentioning the peculiar case of Friedreiclis or Hereditary ataxia, which is usually seen in several children of one family, and is certainly of germinal origin, but is not found in their parents, we may say that definite nervous disorders are not inherited, but that various disorders may arise in consequence of the inheritance of an instability or tendency to disease of the nervous system. Dipsomania. for instance, is not inherited; but the state of the nervous system which leads to dipsomania in the father may often be transmitted to his son. If, however, the alcoholic habit is acquired as the result 
of circumstances, and does not depend upon a primary nervous defect, there is little reason to believe that this acquirement is often transmitted; though even Weismann admits the possibility that persistent nerve fatigue may affect the germ-plasm, and so give rise to neurotic tendencies in the offspring. The subject is too large to be dealt with here. As to the transmission of insanity, this may be added to what has already been said, that "there is no clear case of a normal subject becoming an acute maniac through external shock and transmitting his disease."

Lastly, as to those definite specific diseases which are unquestionably transmitted. These are of germinal origin. Highly typical, and of very great interest in relation to the discoveries of Mendel, ${ }^{1}$ are the "bleeding disease," or hæmophilia, and colour-blindness. These usually show themselves in males, but are transmitted by females. For instance, a colour-blind man had two normal daughters, each of whom had one colour-blind son, whose three normal daughters had four colour-blind sons, and so on, until in the sixth generation there were eight males, of whom seven were colour-blind. Similar genealogical trees, in cases of both of these diseases, might be multiplied without limit. Abnormalities, such as the occurrence of six fingers or toes, may also be traced through as many as half-adozen generations.

1 See Chapter VII. 


\section{CHAPTER XIV}

\section{MENTAL HEREITY}

'THIs concluding chapter is merely a brief addendum, added for the sake of formal completeness. The facts of mental heredity are dealt with at length in the volume on psychology. Thanks to the epochmaking work of Herbert Spencer, the psychology of to-day is essentially an evolutionary or genetic science. The leading problems of psychology are problems in mental inheritance. From the point of view of biology proper, we recognise the unquestionable inheritance, in all animals that possess a nervous system, of a nervous organisation which is intimately correlated with the facts of mind and consciousness. Nearly all the questions discussed in the preceding pages have an inmediate bearing on psychology. One of the chief problems of the psychologist, for instance, is as to the existence of innute ideus, or ideas or "modes of consciousness," or "forms of thought," which are independent of experience. The question arises whether these ideas are independent of individual experience but dependent upon racial experience. This doctrine would appear to imply something very like the inheritance of acquired characters.

All that must be insisted on here, however, is that the physical characters of the brain and spinal cord and system of nerves are subject to the same laws of inheritance as the physical characters of the limbs, or the skeleton, or the internal organs. Pro- 
fessor Pearson has indeed shown that the facts of inheritance of mental and moral characters seem to be precisely parallel to the facts of inheritance of physical characters. The explanation of this parallelism is doubtless to be found in the interdependence of psychical and physical characters.

But I hope to make it plain in the volume on psychology that adequately to discuss the subject of mental heredity would be to write a treatise upon the principles of modern psychology. Such a task is not to be attempted as an appendix to a discussion of heredity in general. 


\section{SU BJEC'T I NDEX}

ACquirements, 15,74

Amphimixis, 32

Atavism, 64

Chromatin, 19

Determinants, 20

Dominant characters, 64

Environment, 71

Gametes, 24

Germ-cells, 24

Germ-plasm, 27

Heredity, definition of, 9 evolutionary importance of, 13

Homogamy, 35

Law and cause-their nature, 48
Law of ancestral inheritance, 42

Libw of regression to mediocrity, 36

Law of segregation, 63

Mutation, 63

Pangenesis, 69

Parthenogonesis, 28

Physiological units, 22

Recapitulation theory, 66

Recessive characters, 61

Tolegony, 81

Variation, 10, 29, sic.

- progressive and regressive, 33 


\section{INDEX TO NAMES}

Bateson, 58

Darwin, 35, 68

Ehrlich, 107

Ellis, Havelock, 98

Ewart, Cossar, 65

Galton, 36, 42

Haeckel, 66, 83

Hertwig, 69

Hall, William, 92

Lamarck, 74

Mackenzie, Leslie, 93
Mendel, 58, 60

Mitchell, Chalmers, 65

Pearson, Karl, 34

Reid, Archdall, 15, 33, 66

Spencer, 13, 21, 56, 89, 115

Thomson, 25, 65

Vernon, 55, 77

Vries, De, 61

Weismann, 19, 26, 31, 54, 73

Weldon, 53 




OCT 201999

बागा?

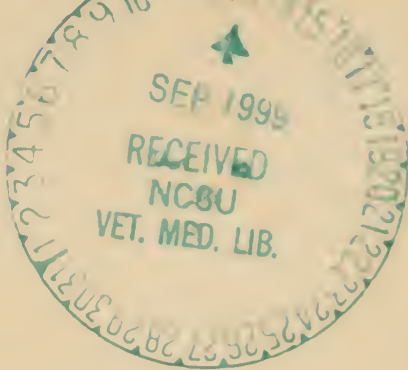



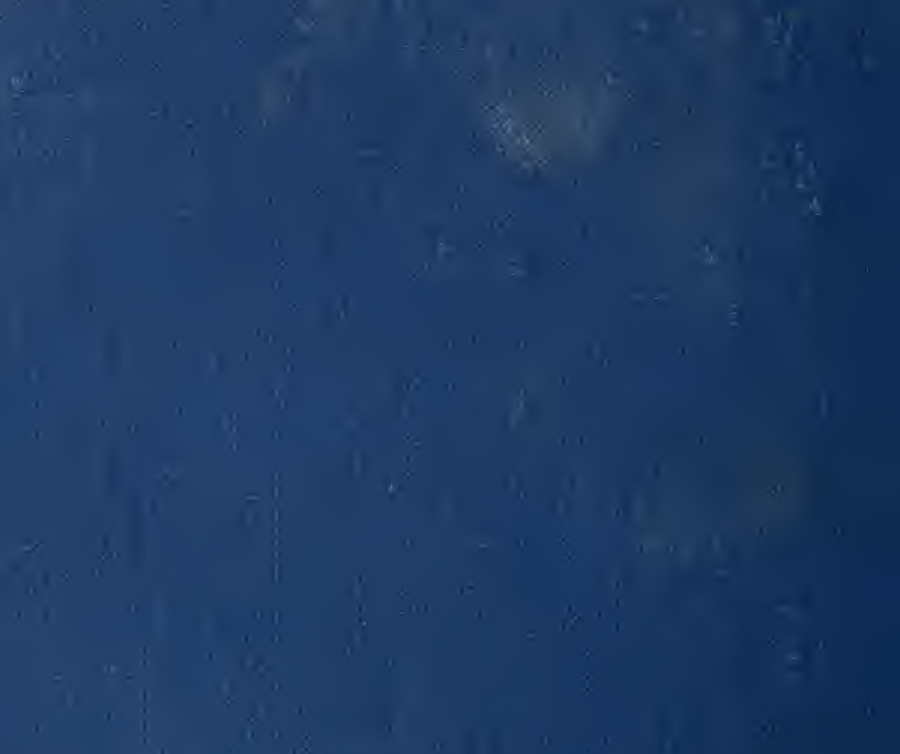

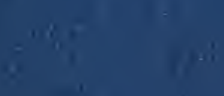

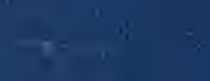

inis,

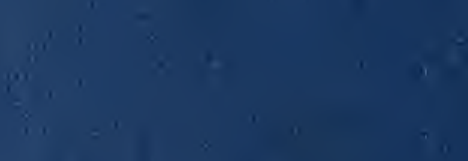

$-2$

19: ', 6

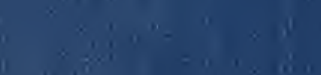

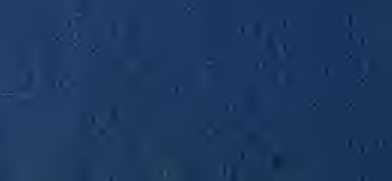

